\title{
Analysis and Design of RC Structure with Light Weight Bricks Using Etabs
}

\author{
Imadabathuni Chandana ${ }^{1}, C H$ Shailaja ${ }^{2}, G$ Ravalika $^{3}$, and $A$ Varsha $^{4}$ \\ ${ }^{1}$ Assistant professor, civil Engineering Department, GRIET, Hyderabad, Telangana, India. \\ ${ }^{2}$ Student civil Engineering Department, GRIET, Hyderabad, Telangana, India. \\ ${ }^{3}$ Student civil Engineering Department, GRIET, Hyderabad, Telangana, India. \\ ${ }^{4}$ Student civil Engineering Department, GRIET, Hyderabad, Telangana, India.
}

\begin{abstract}
A Building has to be defined is an enclosed structure intended for human occupancy. Constructions work has been seen in most of the countries developing with the increase of material cost in the construction work, there is a need to find more cost which can be affordable to people. In the manufacturing of brunt clay bricks, smoke evolved at a great extent and also toxic gases which can harm an environment. So, as to overcome with all these problems. From previous research observed that light weight bricks of Recycle paper mill residue (RPMR) and rice husk ash (RHA) which composes of Recycle paper mill residue (RPMR) and rice husk ash (RHA) and cement which are more economical and eco-friendly. The use of recycle factory residue and rice husk ash bricks are reduce load of wall on beams and columns makes it a relatively lighter members and reducing the hundreds (or) moments. This project includes analysis and design of multi-stored $\mathrm{RC}$ structure $(\mathrm{G}+3)$ with light weight bricks by using ETABS, comparison will be done with conventional bricks.
\end{abstract}

\section{Introduction}

Building construction is that the engineering deals with the development of building like residential houses. In a simple building are often define as an enclose space by walls with roof, food, cloth and therefore the basic needs of citizen. In the early past humans lived in caves, over trees or under trees, to guard themselves from wild animals, rain, sun, etc. as the times passed as humans being started living in huts made from timber branches. The shelters of these old are developed nowadays into beautiful houses. Rich people live in sophisticated condition houses.

A homogeneous mixture of RPMR (Recycle paper mill residue) - RHA (rice husk ash) - cement was prepared with varying proportions, each set comprising of varying percentage of RPMR, RHA and cement were prepared. Sample set A has $80 \%$ RPMR, $10 \%$ RHA and $10 \%$ of cement by weight, sample set B has 75\% RPMR, $15 \%$ RHA and $10 \%$ cement by weight whereas sample set $\mathrm{C}$ has $70 \%$ RPMR, $20 \%$ RHA and $10 \%$ of cement by weight. Results suggests that the optimum mix, both in terms of the strength parameters and overall physico-chemical characteristics will be $80 \%$ RPMR, $10 \%$ RHA and $10 \%$ cement.

In this project, attempt has to been done to replace the red bricks with light weight blocks. The use of light weight block significantly reduces the cost of construction. Compressive strength of RPMR-RHA-cement brick was increased and found to be more than $11 \mathrm{MPa}$ in all the three samples. All brick samples had excellent compressive strength $(11-15 \mathrm{MPa})$ is nearly five times higher than the compressive strength of the conventional burnt clay brick. RHA and RPMR block is a load-bearing construction material that is of lower density $(588 \mathrm{~kg} / \mathrm{m} 3)$ than other construction materials due to its high porosity. Due to its lower density of these blocks, tall buildings constructed using these blocks have less need for steel and concrete for structural members.

This project mainly deals with the comparative analysis of conventional bricks and light weight bricks, results which are obtained from the analysis of a multi storied building where analyzed by using ETABS software.

\section{METHODOLOGY}

\section{Steps to Analyse and Design of Building:}

Creating of grid points and generation of structure- After getting opened the program, select a new model and a window appears where we had entered the details of grid dimensions and story dimensions of our building. Here the program had generated 2D and 3D structure by specifying the building details in the two windows. 


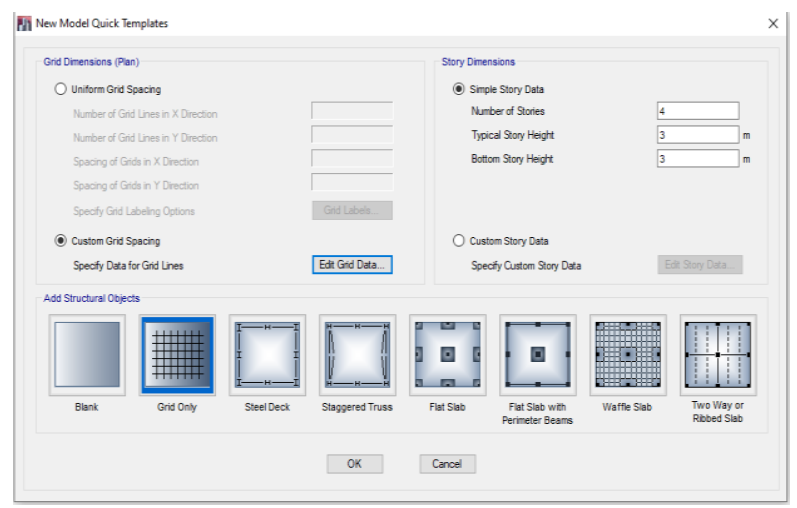

Fig. 1. Creation of grid points \& structure generation

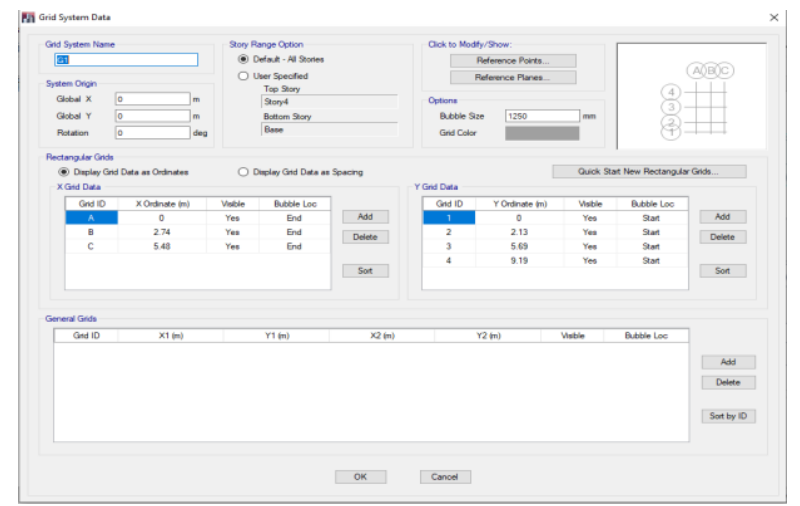

Fig. 2. Grid system data

1. Defining of fabric property and sectional property. After making the grids, begin to outline the fabric property bychoosing outline menu-material properties (define concrete and steel reinforcement). afterward outline section properties (beams, columns, slabs and wall) bygivingthe required details in shaping. Afterward we tend to outline section size bychoosingframe sections as shown below and supplementarythe desired section for beams, column etc.'

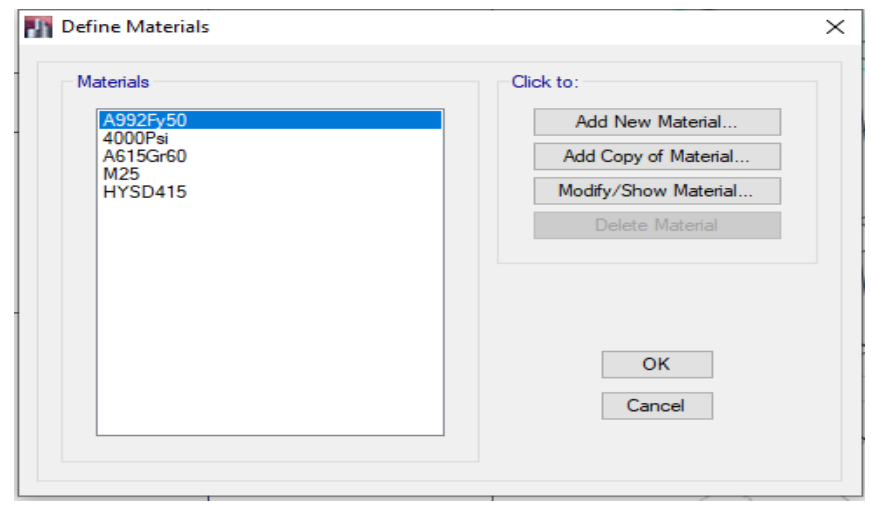

Fig. 3. Defining the material properties

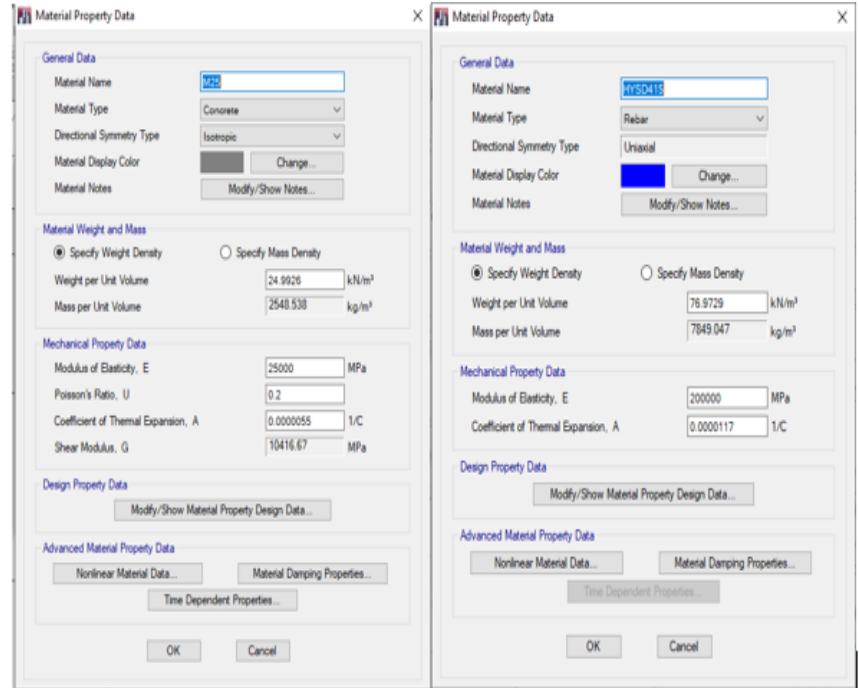

Fig. 4. Assigning of material property data

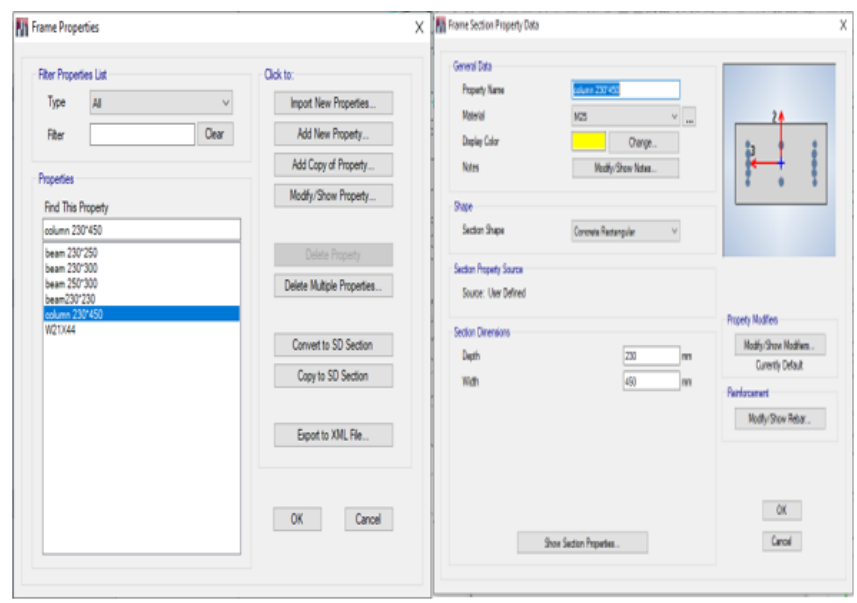

Fig.5. Assigning of sectional property data

2. Assigning of defined properties to the grid points. After defining the property for material and section properties, now draw the structural components using command menu $>$ Draw line for beam and create column in degion for columns by which property assigning is completed for beams and columns sections.

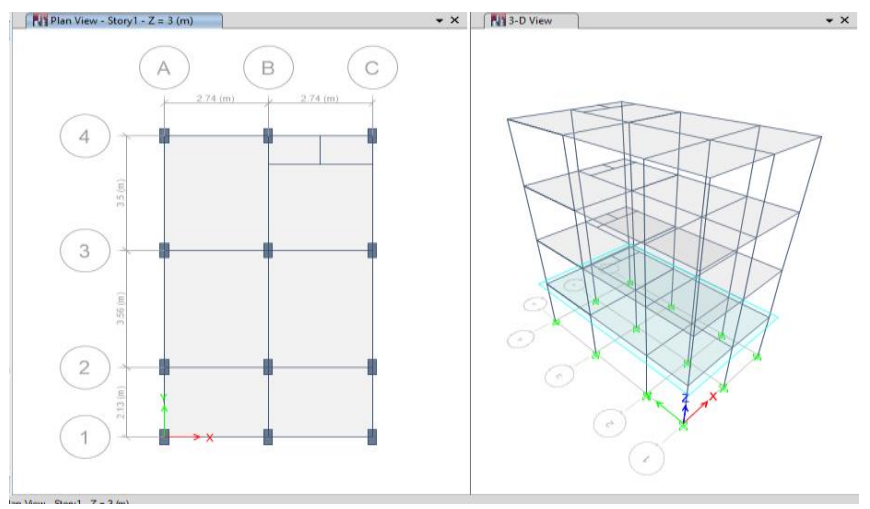

Fig.6. Assigning of different properties to the grid points 
3. Assigning of supports. After drawing the details of building (beams, columns slabs, wall), now assign the supports by going to assign menu $>$ joint menu $>$ restraints $>$ fixed.

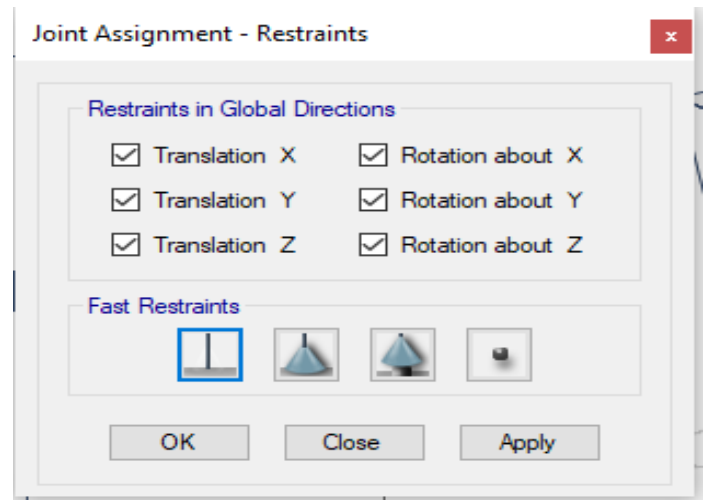

Fig.7. Assigning of supports

4. Defining of loads. The loads in ETABS program are defined as using static load cases command in define menu.

5. Assigning of dead load (IS 875:1987 part 1).After defining all the loads, dead loads are assigned for external walls and internal walls, slabs. As per IS:875(part-1) -1987, Indian Standard code of practice dead load include weight of walls (exterior and interior walls) floor finishes, false ceilings and the permanent constructions within the buildings.
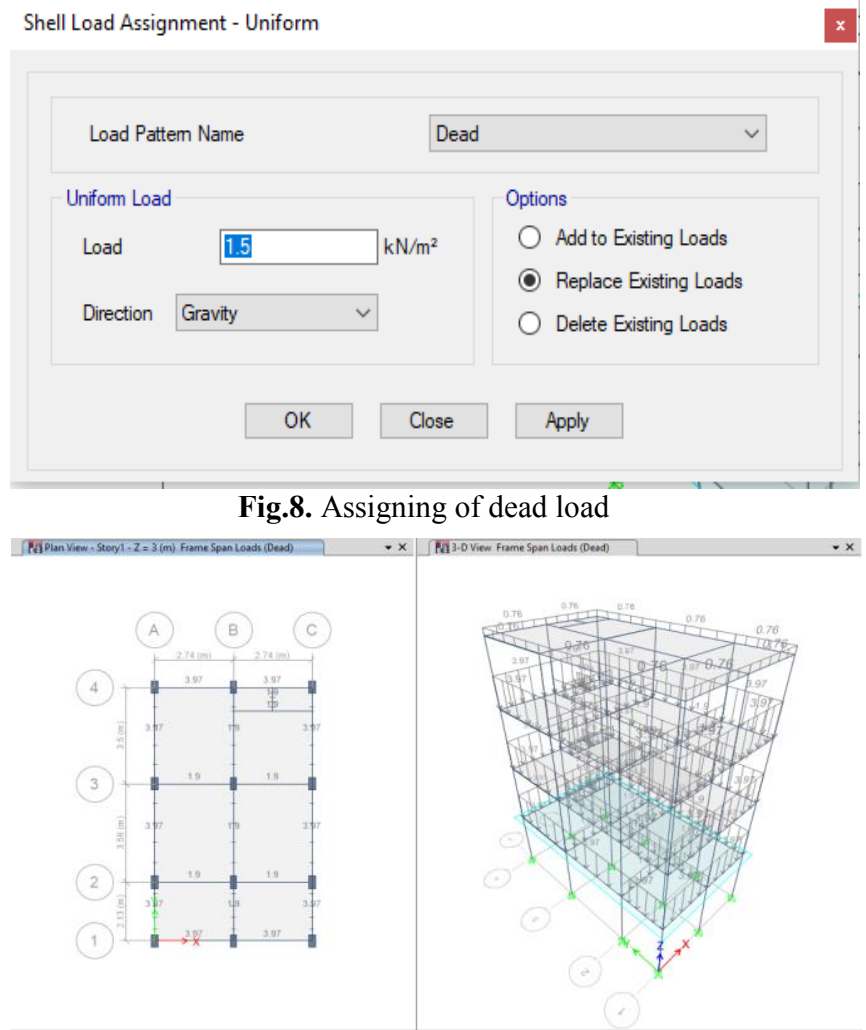

Fig.9. Loading diagram of dead loads
6. Assigning of Live load (IS 875:1987 part 2).Live loads are assigned for the entire structure including floor finishing. This load is created by the moving loads, distributed and targeted masses and also with the supposed use or occupancy of a building.

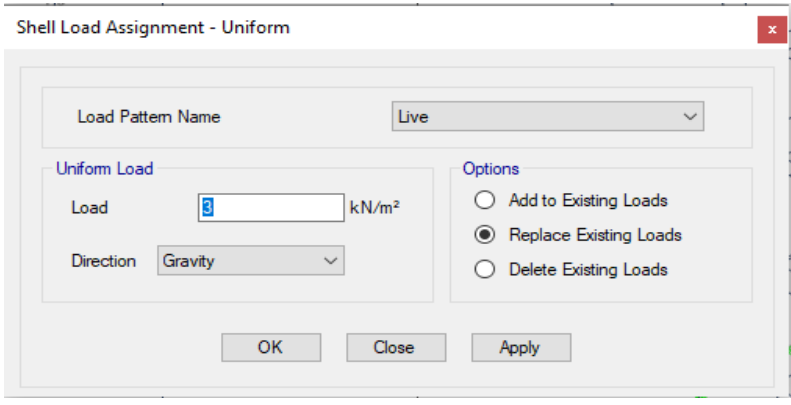

Fig.10. Assigning of live load

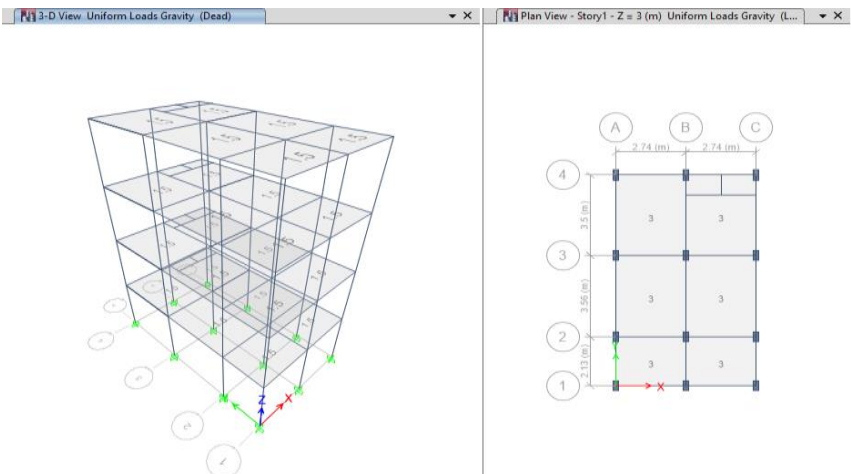

Fig.11. Loading diagram of live load and dead load

7. Assigning of load combinations (IS 875:1987 part 5).Load combinations are given based on IS $875: 1987$ Part 5 using load combinations command in define menu.

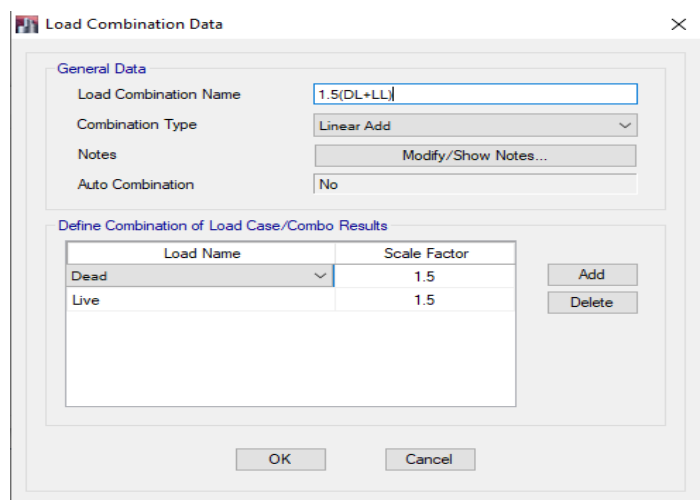

Fig.12. Assigning of load combinations

8. Analysing and checking all the errors. After completion of all steps above, now perform the analysis and check the errors. Errors occurred are resolved at the located frame and section. 


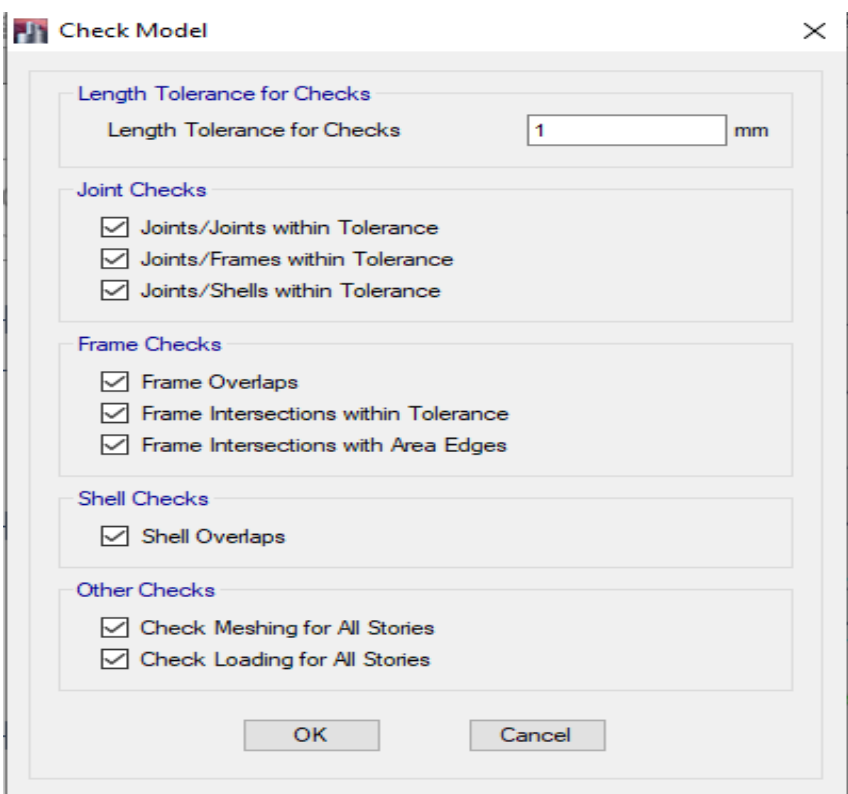

Fill Warning Model has been checked. No waming messages were generated.]
Fig.13. Performing the analysis and checking the errors

9. Performing of concrete design on the structure as per IS 456: 2000 code book. This step considers the last step of procedure. After completing the analysis, now perform concrete design on the structure as per IS code of practice. For this go to Design menu $>$ concrete design $>$ select design combinations. After this again go to design menu $>$ concrete frame design $>$ Start design check of structure. Then the ETABS software performs the design for every structural element.

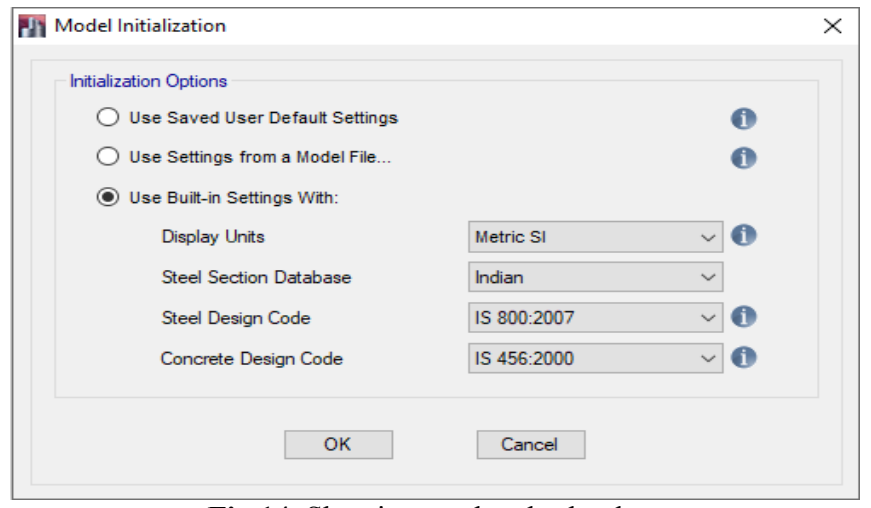

Fig.14. Showing used codes books

\section{CALCULATIONS LOAD CALCULATIONS:}

The load calculation of the structure is calculated as follows;

$\begin{array}{lll}> & \text { Live Load } & : 3 \mathrm{kN} / \mathrm{m} 2 \\ > & \text { Dead Load (floor finishes) } & : 1.5 \mathrm{kN} / \mathrm{m} 2 \\ & \text { Wall Loads (light weight bricks) } & \end{array}$

- For 9" wall - $0.23 \times 3 \times 5.76=3.973 \mathrm{kN} / \mathrm{m}$

- For 4.5 " wall - $0.11 \times 3 \times 5.76=1.903 \mathrm{kN} / \mathrm{m}$

- For parapet wall - $0.11 \times 1.2 \times 5.76=0.760 \mathrm{kN} / \mathrm{m}$

Wall Loads (conventional bricks)

- For 9" wall $\quad-0.23 \times 17.65 \times 3=12.183 \mathrm{kN} / \mathrm{m}$

- For 4.5" wall - $0.11 \times 17.65 \times 3=5.833 \mathrm{kN} / \mathrm{m}$

- For parapet wall - $0.11 \times 17.65 \times 1.2=2.33 \mathrm{kN} / \mathrm{m}$

\section{DESIGN AND ANALYSIS}

After the detailed analysis of structure, the following results are obtained which shows the area of steel required in respective structural members (beams, columns, shear walls). Along with the steel area, the bending moment details, shear force details and deflections in each beam is also obtained in a systematic manner. All these details are obtained in an auto generated file which is generated automatically by ETABS software while we work on the structure. Necessary snapshots are given in this chapter.

As beams, columns and slabs are designed in detailed manner in ETABS, the design of footing is done in Microsoft Excel Spreadsheets. Also manual calculations have been performed for Beams, slabs and columns and checked with software results.

After obtaining the detailed design reports and necessary AutoCAD plans, the 3D modelling of the structure is carried out in E-TABS for analysis and design. We have also done the Rebar Modelling which shows the reinforcement details structural members as per the design.

\section{STRUCTURE DATA Story Data}

Table 1. Story Data

\begin{tabular}{|c|c|c|c|c|c|}
\hline Name & $\begin{array}{c}\text { Heigh } \\
\mathrm{t} \\
\mathrm{mm}\end{array}$ & $\begin{array}{c}\text { Elevati } \\
\text { on } \\
\mathrm{mm}\end{array}$ & $\begin{array}{c}\text { Master } \\
\text { Story }\end{array}$ & $\begin{array}{c}\text { Simila } \\
\mathrm{r} \text { To }\end{array}$ & $\begin{array}{c}\text { Splice } \\
\text { Story }\end{array}$ \\
\hline Story4 & 3000 & 12000 & No & None & No \\
\hline Story3 & 3000 & 9000 & No & Story4 & No \\
\hline Story2 & 3000 & 6000 & No & Story4 & No \\
\hline Story1 & 3000 & 3000 & No & Story4 & No \\
\hline Base & 0 & 0 & No & None & No \\
\hline
\end{tabular}




\section{Grid Data}

\begin{tabular}{|c|c|c|c|c|c|c|c|}
\hline $\begin{array}{c}\text { Nam } \\
\mathrm{e}\end{array}$ & Type & $\begin{array}{c}\text { Story } \\
\text { Range }\end{array}$ & $\begin{array}{c}\mathrm{X} \\
\text { Origi } \\
\mathrm{n} \\
\mathrm{m}\end{array}$ & $\begin{array}{c}\mathrm{Y} \\
\text { Origi } \\
\mathrm{n} \\
\mathrm{m}\end{array}$ & $\begin{array}{c}\text { Rotatio } \\
\mathrm{n} \\
\operatorname{deg}\end{array}$ & $\begin{array}{c}\text { Bubbl } \\
\text { e Size } \\
\mathrm{mm}\end{array}$ & Color \\
\hline $\mathrm{G}+3$ & $\begin{array}{c}\text { Cartesia } \\
n\end{array}$ & $\begin{array}{c}\text { Defaul } \\
t\end{array}$ & 0 & 0 & 0 & 1250 & $\begin{array}{c}\text { GRA } \\
Y\end{array}$ \\
\hline
\end{tabular}

Table 3. Grid Lines

\begin{tabular}{|c|c|c|c|c|c|}
\hline $\begin{array}{c}\text { Grid } \\
\text { System }\end{array}$ & $\begin{array}{c}\text { Grid } \\
\text { Direction }\end{array}$ & $\begin{array}{c}\text { Grid } \\
\text { ID }\end{array}$ & Visible & $\begin{array}{c}\text { Bubble } \\
\text { Location }\end{array}$ & $\begin{array}{c}\text { Ordinate } \\
\mathrm{m}\end{array}$ \\
\hline $\mathrm{G}+3$ & $\mathrm{X}$ & A & Yes & End & 0 \\
\hline $\mathrm{G}+3$ & $\mathrm{X}$ & $\mathrm{B}$ & Yes & End & 2.74 \\
\hline $\mathrm{G}+3$ & $\mathrm{X}$ & $\mathrm{C}$ & Yes & End & 5.48 \\
\hline $\mathrm{G}+3$ & $\mathrm{Y}$ & 1 & Yes & Start & 0 \\
\hline $\mathrm{G}+3$ & Y & 2 & Yes & Start & 2.13 \\
\hline $\mathrm{G}+3$ & $\mathrm{Y}$ & 3 & Yes & Start & 5.69 \\
\hline $\mathrm{G}+3$ & $\mathrm{Y}$ & 4 & Yes & Start & 9.19 \\
\hline
\end{tabular}

\section{PROPERTIES}

\section{Materials}

Table 4. Material Properties - Summary

\begin{tabular}{|c|c|c|c|c|c|}
\hline Name & Type & $\begin{array}{c}\mathrm{E} \\
\mathrm{MPa}\end{array}$ & $v$ & $\begin{array}{c}\text { Unit } \\
\text { Weight } \\
\mathrm{kN} / \mathrm{m}^{3}\end{array}$ & $\begin{array}{c}\text { Design } \\
\text { Strengths }\end{array}$ \\
\hline HYSD415 & Rebar & 200000 & 0 & 76.9729 & $\begin{array}{l}\mathrm{Fy}=415 \mathrm{MPa} \\
\mathrm{Fu}=485 \mathrm{MPa}\end{array}$ \\
\hline M25 & Concrete & 25000 & 0.2 & 24.9926 & $\mathrm{Fc}=25 \mathrm{MPa}$ \\
\hline
\end{tabular}

\section{Frame Sections}

The Frame sections that is columns and beams that are used in the structure are given with the material, shape and size used

Table 5. Frame Sections for conventional bricks

\begin{tabular}{|c|c|c|c|}
\hline Name & Material & Shape & Size \\
\hline $\begin{array}{c}\text { B1 - 230 } \\
300\end{array}$ & M25 & $\begin{array}{c}\text { Concrete } \\
\text { Rectangular }\end{array}$ & $\begin{array}{c}230 \mathrm{~mm} \mathrm{X} \\
300 \mathrm{~mm}\end{array}$ \\
\hline $\begin{array}{c}\text { B2 - 230 } \\
250\end{array}$ & M25 & $\begin{array}{c}\text { Concrete } \\
\text { Rectangular }\end{array}$ & $\begin{array}{c}230 \mathrm{~mm} \mathrm{X} \\
250 \mathrm{~mm}\end{array}$ \\
\hline $\begin{array}{c}\text { B3 - 230 } \\
230\end{array}$ & M25 & $\begin{array}{c}\text { Concrete } \\
\text { Rectangular }\end{array}$ & $\begin{array}{c}230 \mathrm{~mm} \mathrm{X} \\
230 \mathrm{~mm}\end{array}$ \\
\hline $\begin{array}{c}\text { C 230 } \\
450\end{array}$ & M25 & $\begin{array}{c}\text { Concrete } \\
\text { Rectangular }\end{array}$ & $\begin{array}{c}230 \mathrm{~mm} \mathrm{X} \\
450 \mathrm{~mm}\end{array}$ \\
\hline
\end{tabular}

\section{Shell Sections}

Table 6. Shell Sections - Summary

\begin{tabular}{|c|c|c|c|c|}
\hline Name & $\begin{array}{c}\text { Design } \\
\text { Type }\end{array}$ & $\begin{array}{c}\text { Element } \\
\text { Type }\end{array}$ & Material & $\begin{array}{c}\text { Total } \\
\text { Thickness } \\
\text { mm }\end{array}$ \\
\hline Slab120 & Slab & Shell-Thin & M25 & 120 \\
\hline
\end{tabular}

\section{Reinforcement Sizes}

The following reinforcement sizes are used for the structures.

Table 7. Reinforcing Bar Sizes for conventional building

\begin{tabular}{|c|c|c|}
\hline Name & $\begin{array}{c}\text { Diameter } \\
\mathbf{m m}\end{array}$ & $\begin{array}{c}\text { Area } \\
\mathbf{m m}^{\mathbf{2}}\end{array}$ \\
\hline 12 & 12 & 113 \\
\hline 16 & 16 & 201 \\
\hline 25 & 25 & 491 \\
\hline 26 & 26 & 531 \\
\hline
\end{tabular}

Table 8. Reinforcing Bar Sizes for light weight building

\begin{tabular}{|c|c|c|}
\hline Name & $\begin{array}{c}\text { Diameter } \\
\mathbf{m m}\end{array}$ & $\begin{array}{c}\text { Area } \\
\mathbf{m m}^{\mathbf{2}}\end{array}$ \\
\hline 10 & 10 & 79 \\
\hline 12 & 12 & 113 \\
\hline 16 & 16 & 201 \\
\hline 20 & 20 & 314 \\
\hline
\end{tabular}

\section{LOADS}

The loading information is applied to the models as shown below.

\section{Load Patterns}

Table 9. Load Patterns

\begin{tabular}{|c|c|c|}
\hline Name & Type & $\begin{array}{c}\text { Self Weight } \\
\text { Multiplier }\end{array}$ \\
\hline Dead & Dead & 1 \\
\hline Live & Live & 0 \\
\hline
\end{tabular}

\section{Load Cases}

Table 10. Load Cases - Summary

\begin{tabular}{|c|c|}
\hline Name & Type \\
\hline Dead & Linear Static \\
\hline Live & Linear Static \\
\hline
\end{tabular}

\section{Load Combinations}

Table 11. Load Combinations

\begin{tabular}{|c|c|c|c|c|}
\hline Name & $\begin{array}{c}\text { Load } \\
\text { Case/Combo }\end{array}$ & $\begin{array}{c}\text { Scale } \\
\text { Factor }\end{array}$ & Type & Auto \\
\hline $\begin{array}{c}1.5(\mathrm{DL}+ \\
\text { LL) }\end{array}$ & Dead & 1.5 & Linear Add & No \\
\hline $\begin{array}{c}1.5(\mathrm{DL}+ \\
\text { LL) }\end{array}$ & Live & 1.5 & & No \\
\hline
\end{tabular}

\section{ANALYSIS RESULTS}




\section{SFD and BMD of Conventional Building}

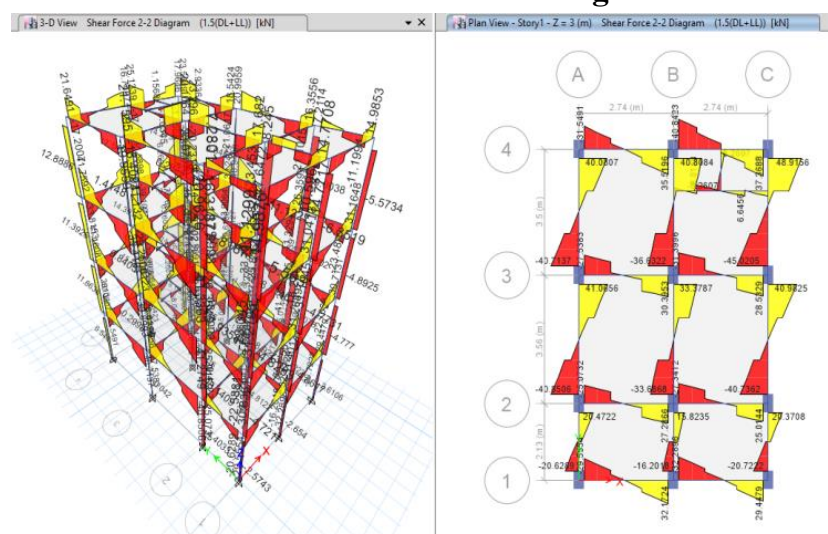

Fig.15. SFD of conventional building

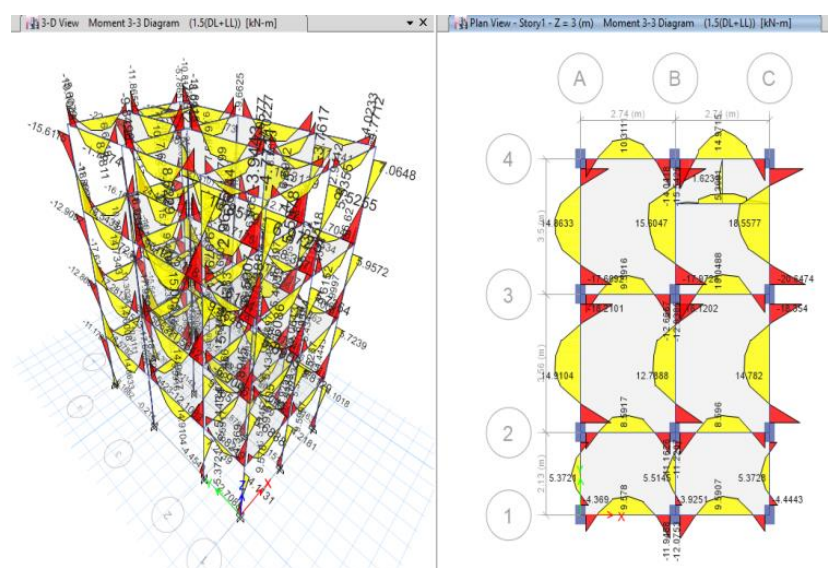

Fig.16. BMD of conventional building

\section{SFD and BMD of Light Weight Building}

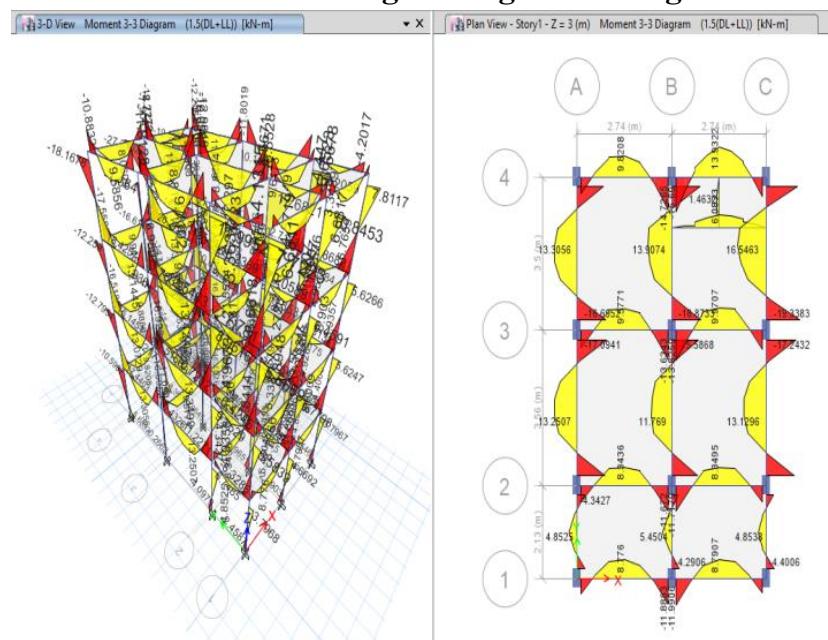

Fig.17. SFD of Light weight building

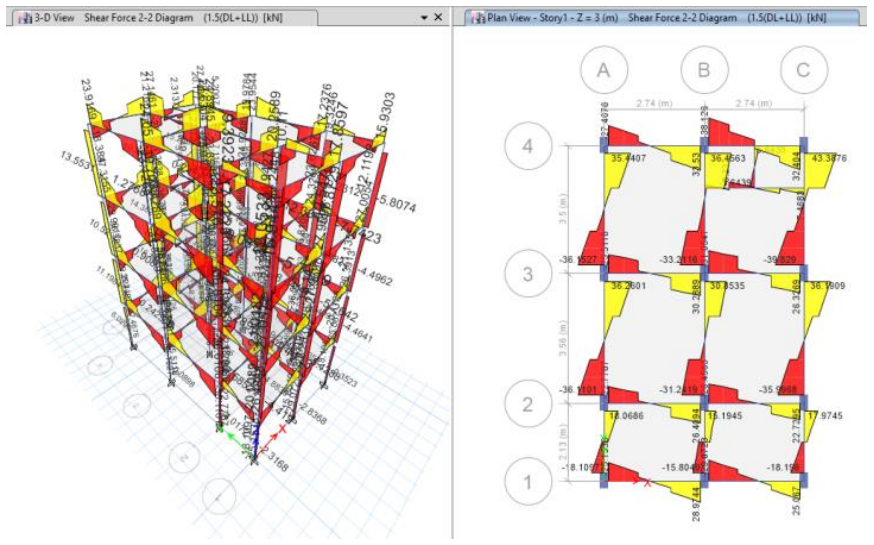

Fig.18. BMD of Light weight building

\section{Deformed Shapes}
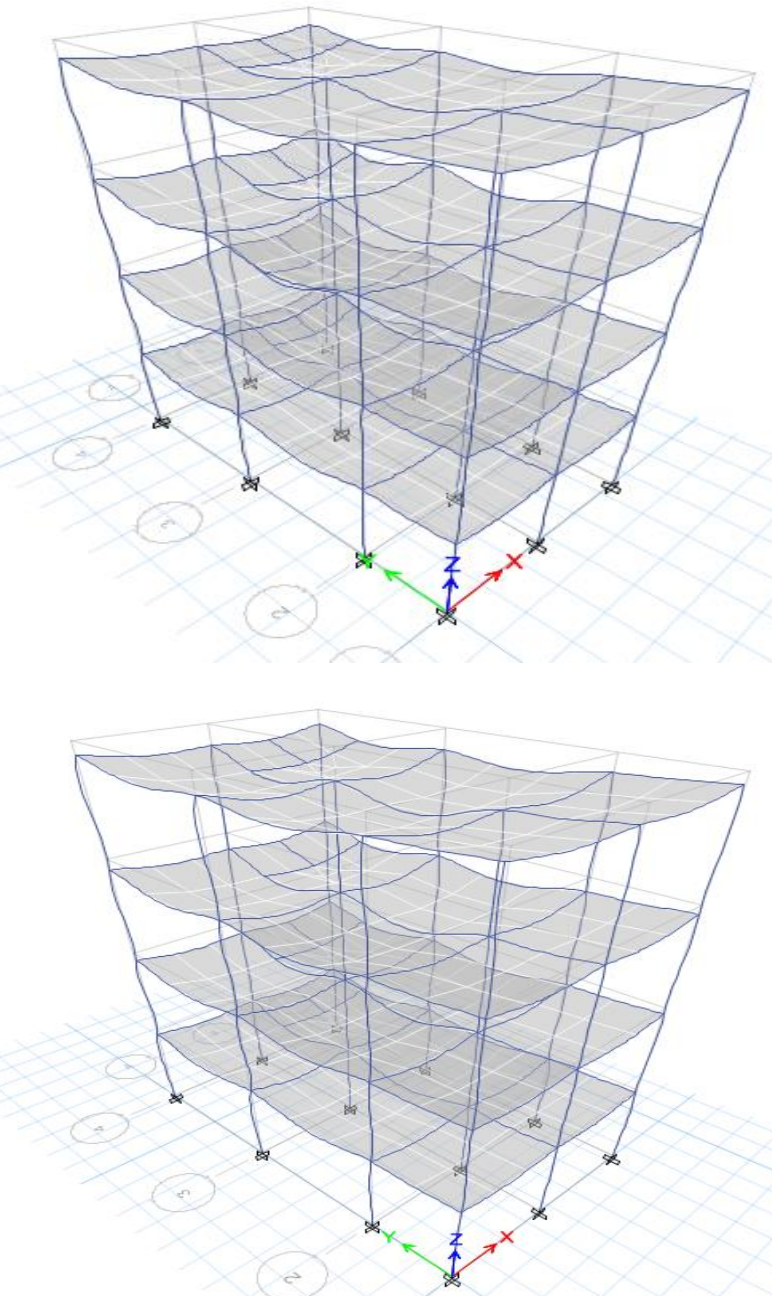

Fig.19. Displacements of Conventional and Light Weight Buildings 


\section{DESIGN RESULTS}

\section{Longitudinal reinforcement for different stories of} conventional building

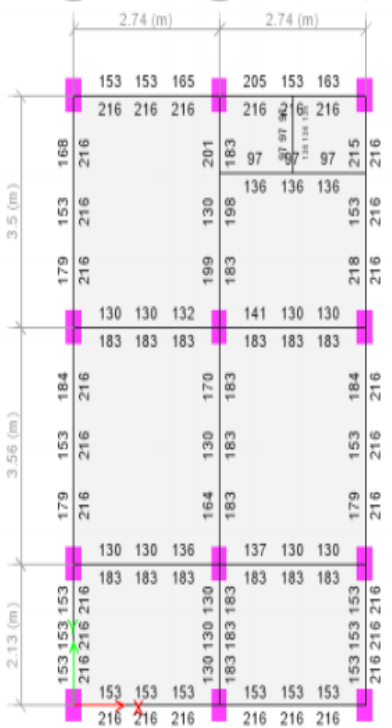

Storyl

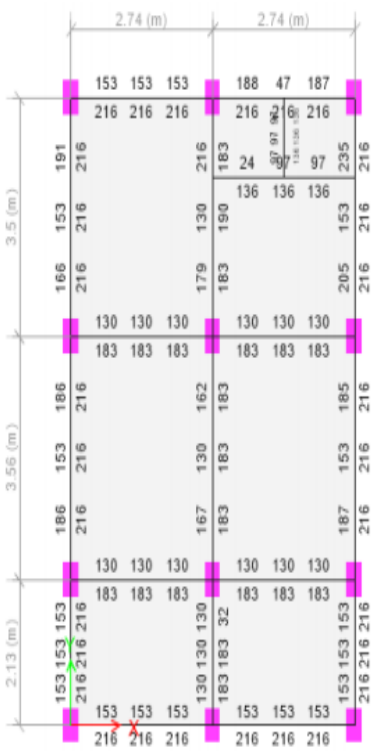

Story3

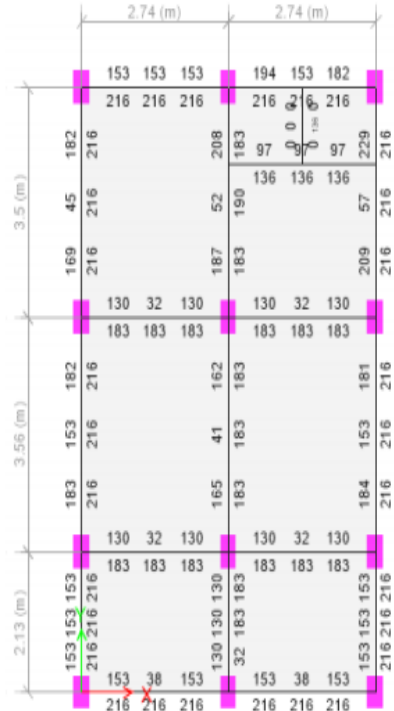

Story2

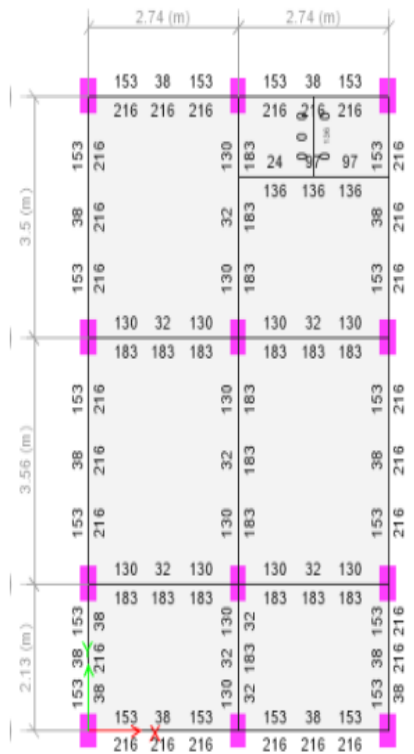

Story4
Fig.20. Plan views of longitudinal reinforcement details of different stories

Longitudinal Reinforcement for Different Stories of

Light Weight Building

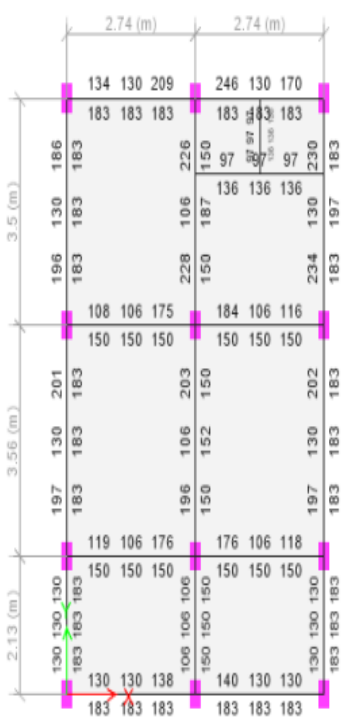

Storyl

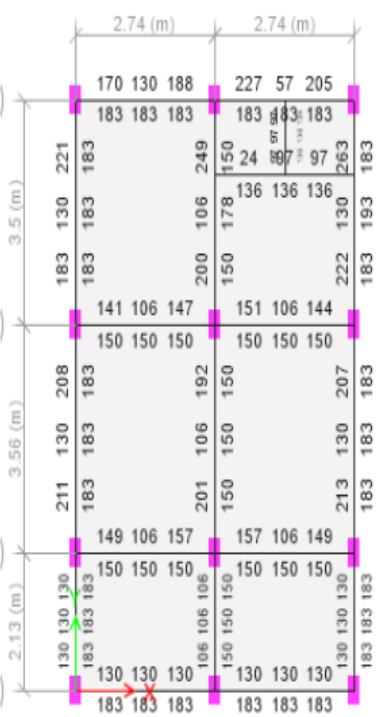

Story3

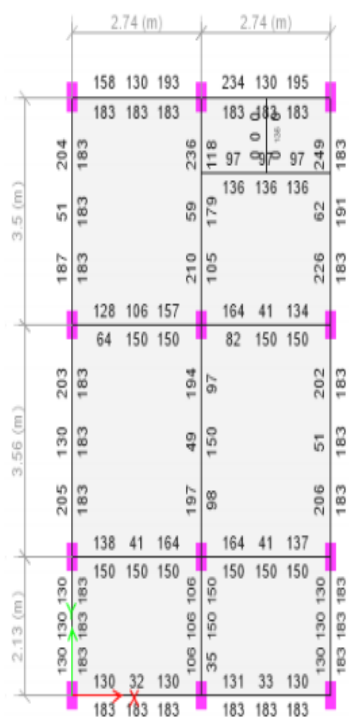

Story2

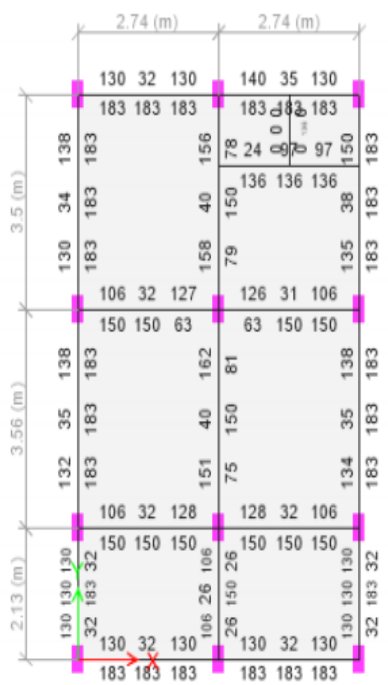

Story4
Fig.21. Plan views of longitudinal reinforcement details of different stories 
Rebar percentage for Different Stories of Conventional Building

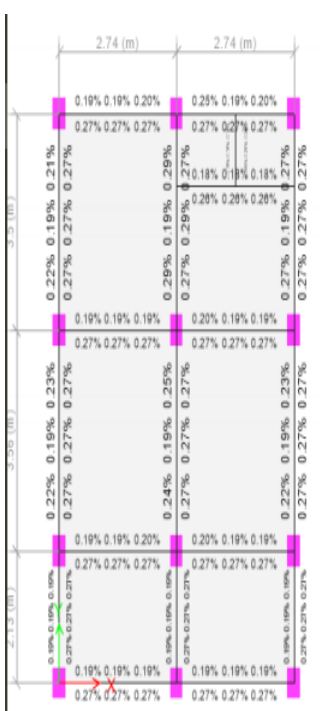

Storyl

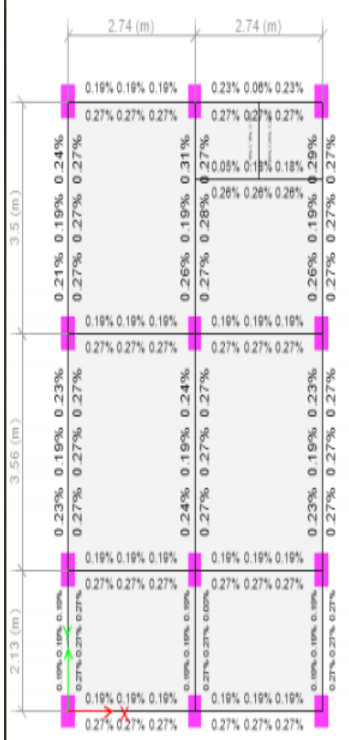

Story3

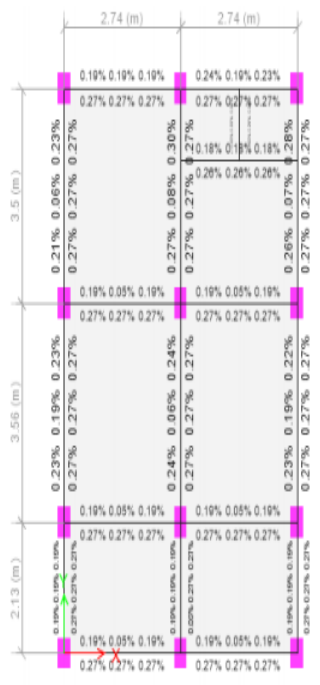

Story2

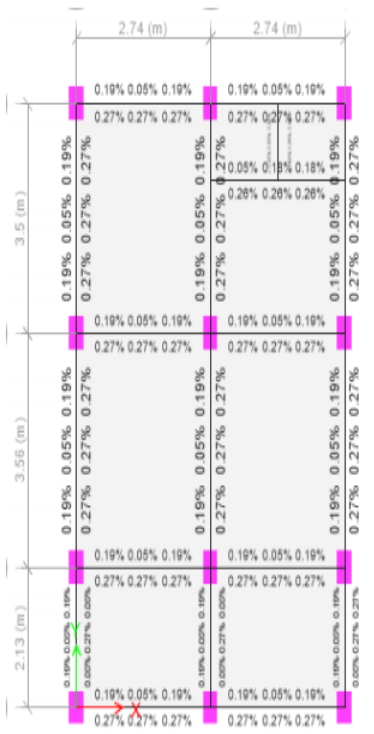

Story4
Fig.22. Plan views of Rebar Percentage of different stories
Rebar percentage for Different Stories of Light Weight Building
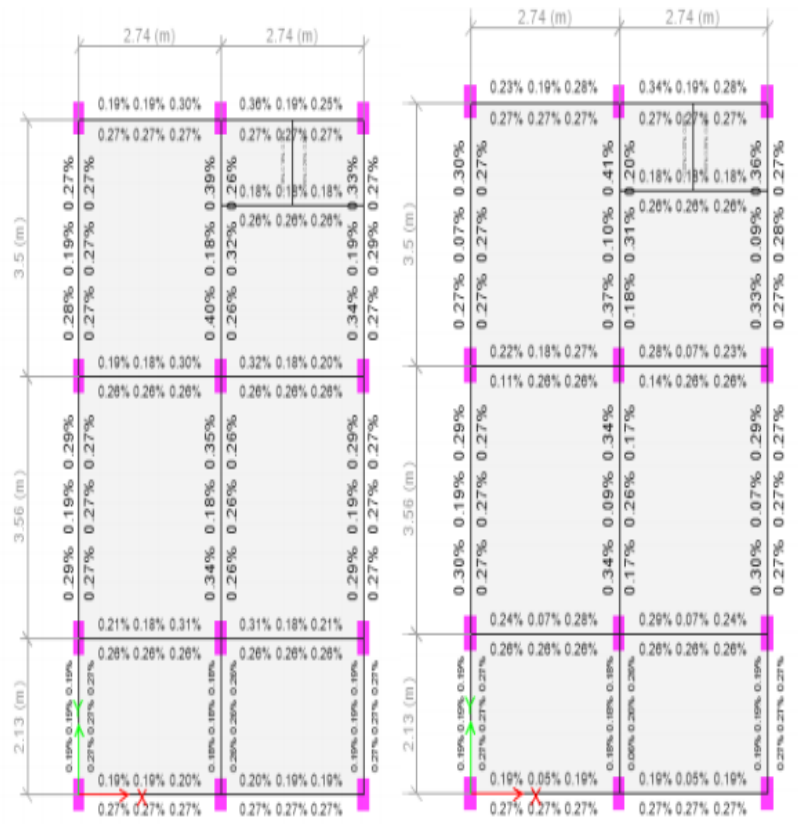

Storyl

Story2
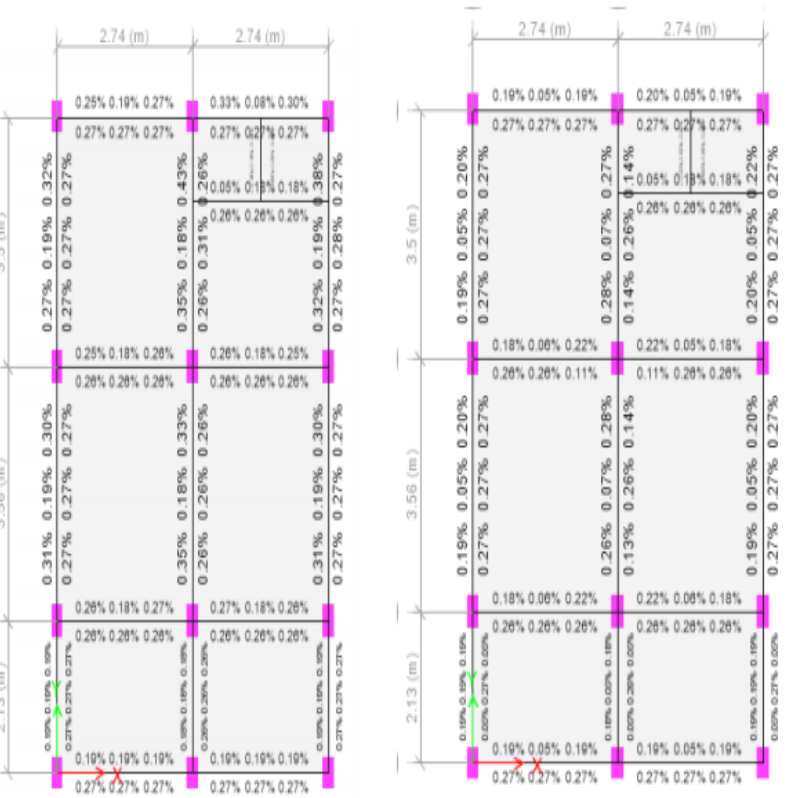

Story3
Fig.23. Plan views of Rebar Percentage of different stories

Shear Reinforcement for Different Stories of Conventional Building 

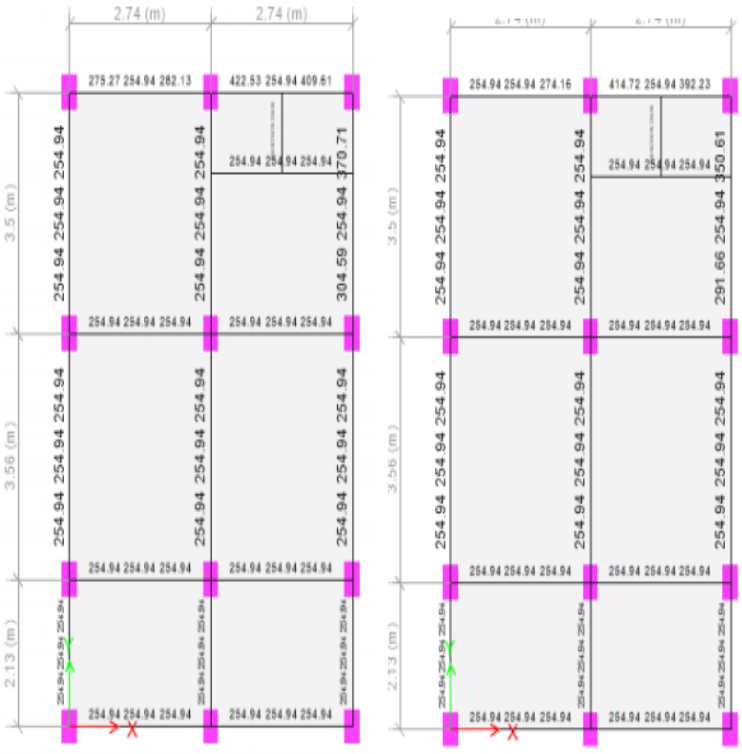

Storyl
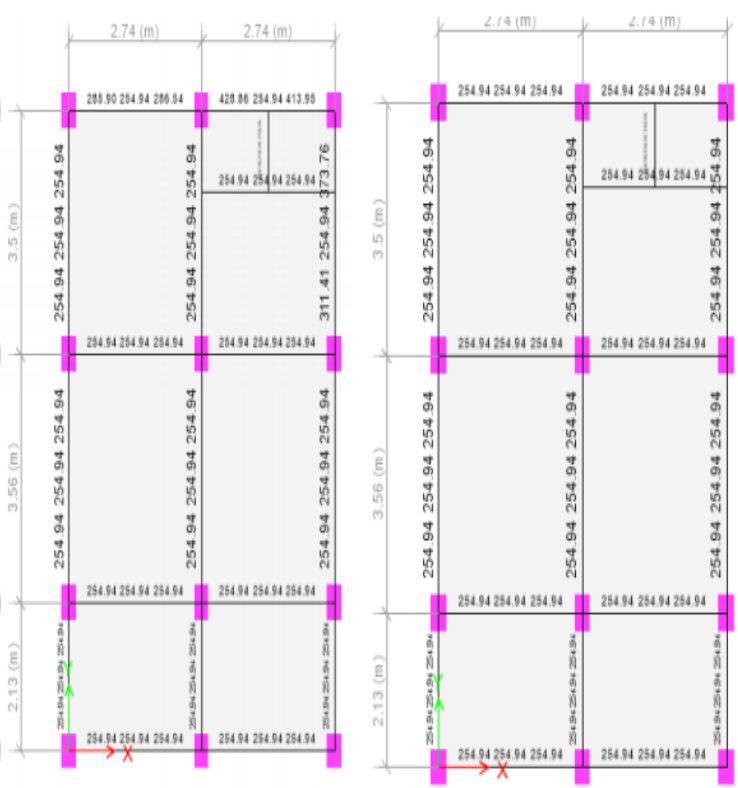

Story3

Story4

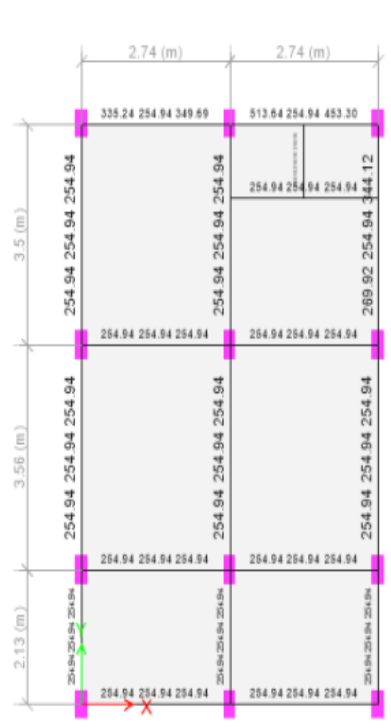

Storyl

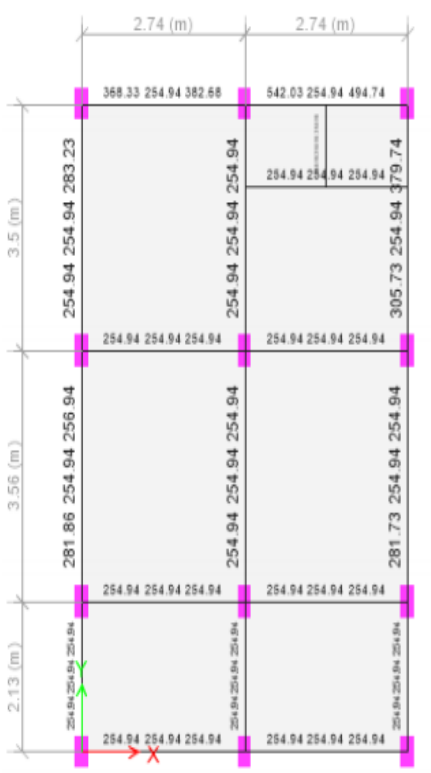

Story3

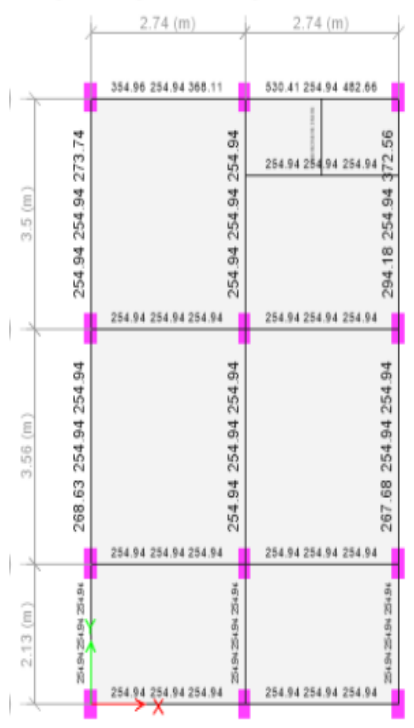

Story2

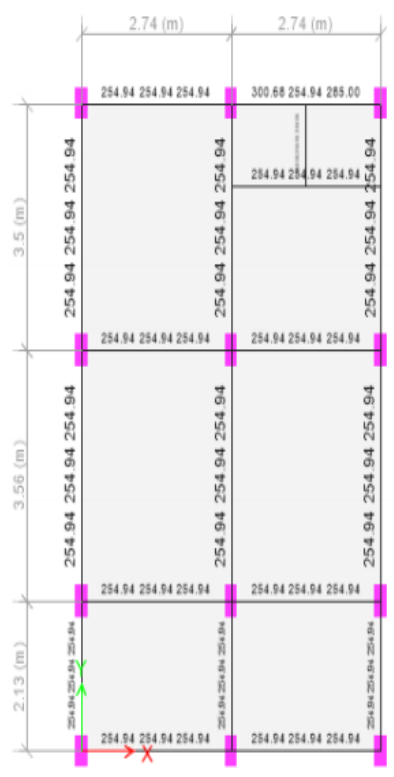

Story4
Fig.24. Plan views of Shear Reinforcement details of different stories
Fig.25. Plan views of Shear Reinforcement details of different stories

\section{Shear Reinforcement for Different Stories of Light} Weight Building

\section{RESULTS AND DISCUSSIONS}

Structural Modelling of Building in E-TABS 2017 


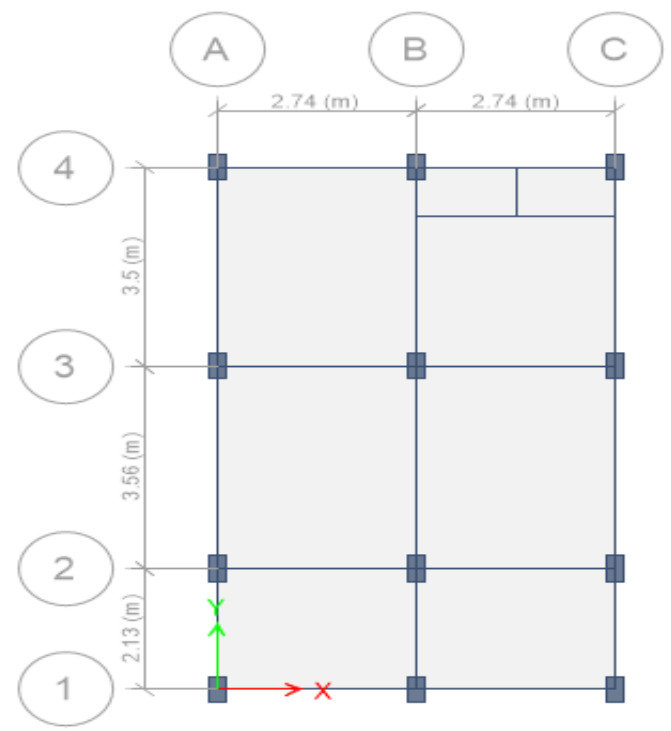

Fig.26. Plan of the model

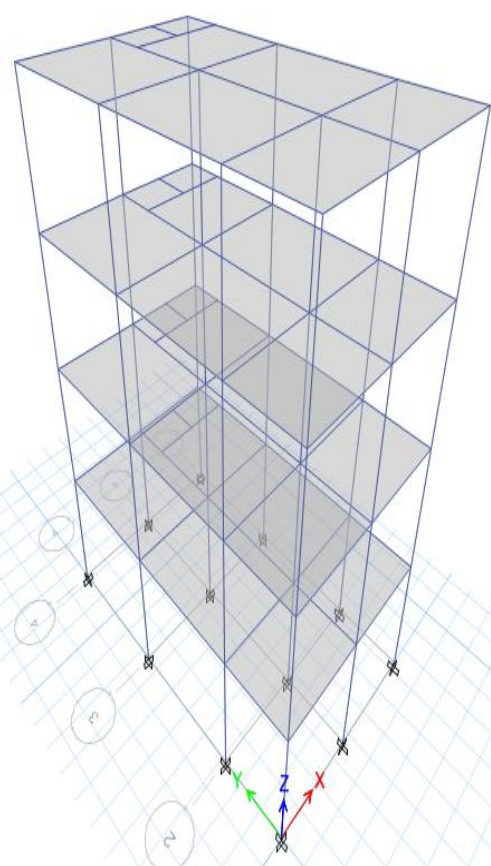

Fig.27. 3D view of the model

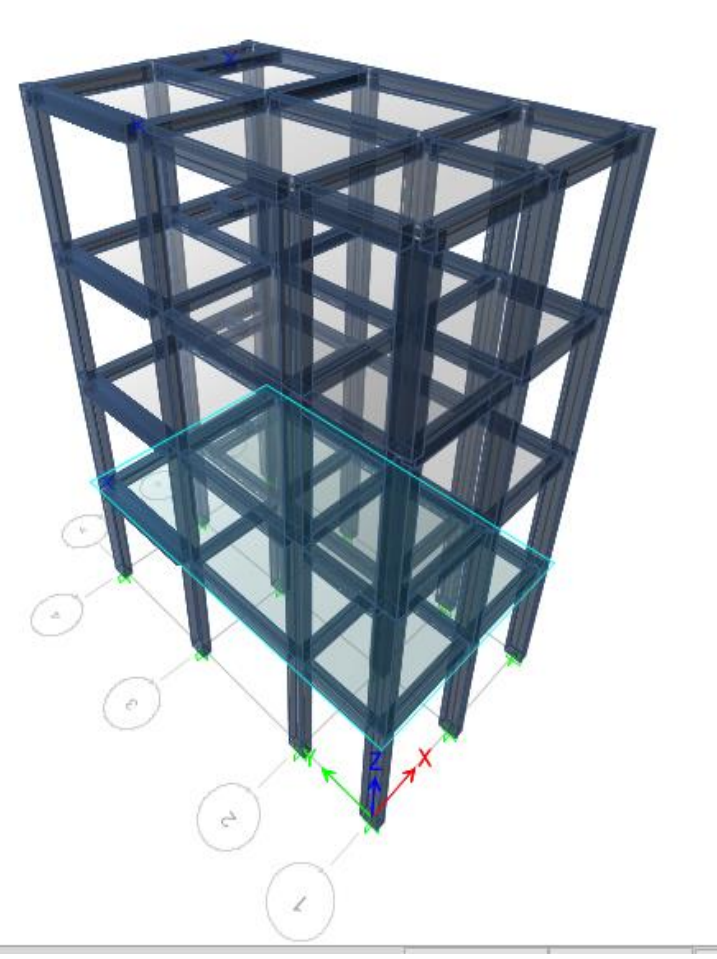

Fig.28. 3D-Render view of the model

\section{Structural Details of a Building with Conventional and Light Weight Bricks at story 1}

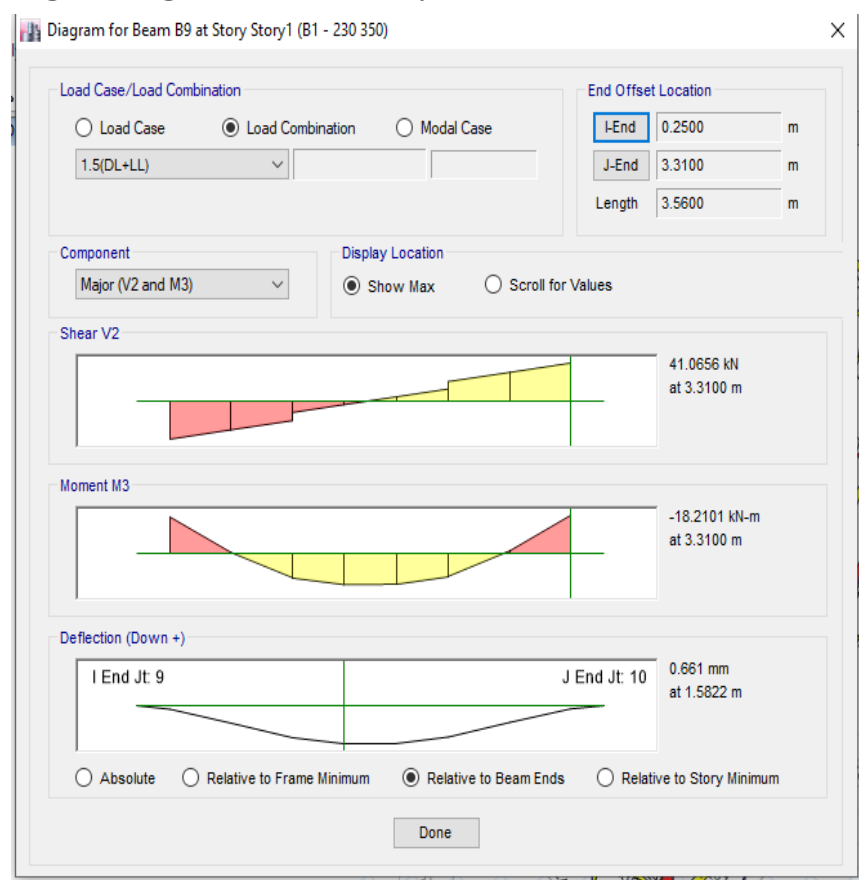

Fig.29. Maximum SF and BM of Beam B9 of conventional building 


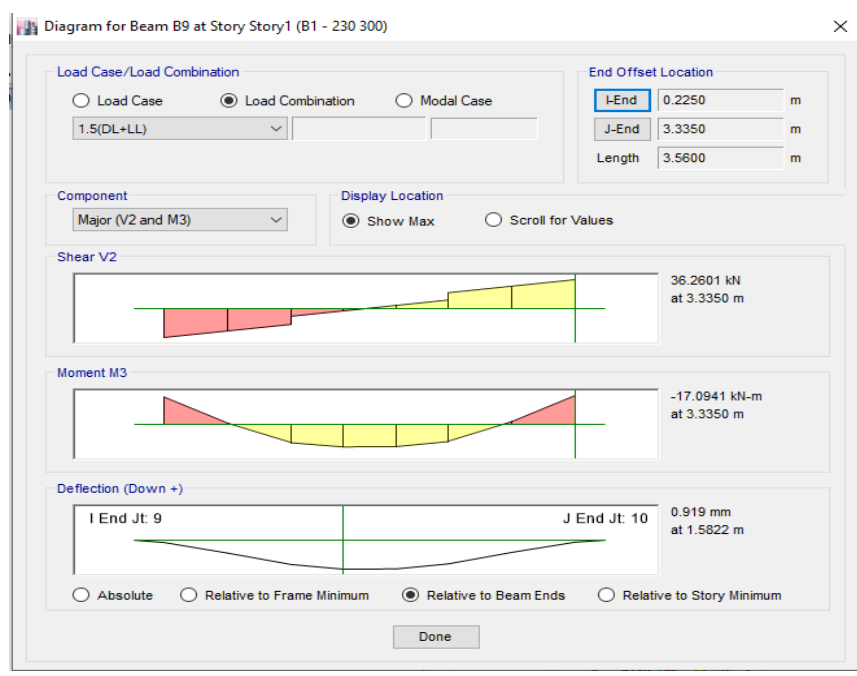

Fig.30. maximum SF and BM of Beam B9 of Light Weight building

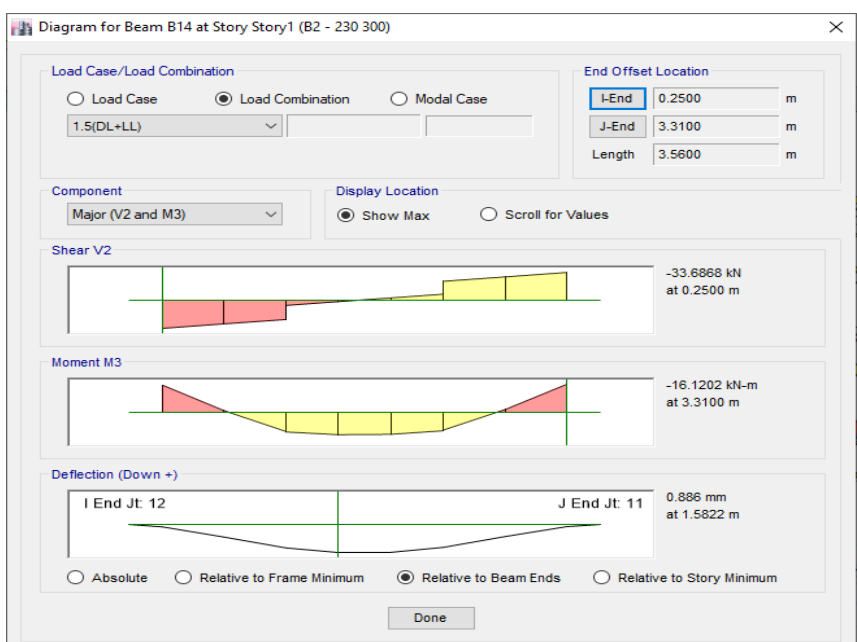

Fig.31. Maximum SF and BM of Beam B14 of conventional building

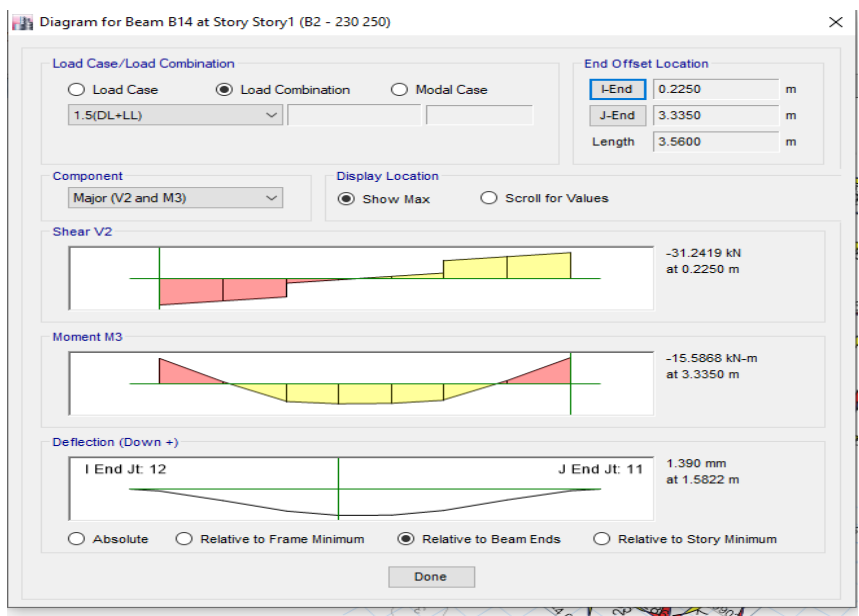

Fig.33. maximum SF and BM of column $\mathrm{C} 1$ of conventional building

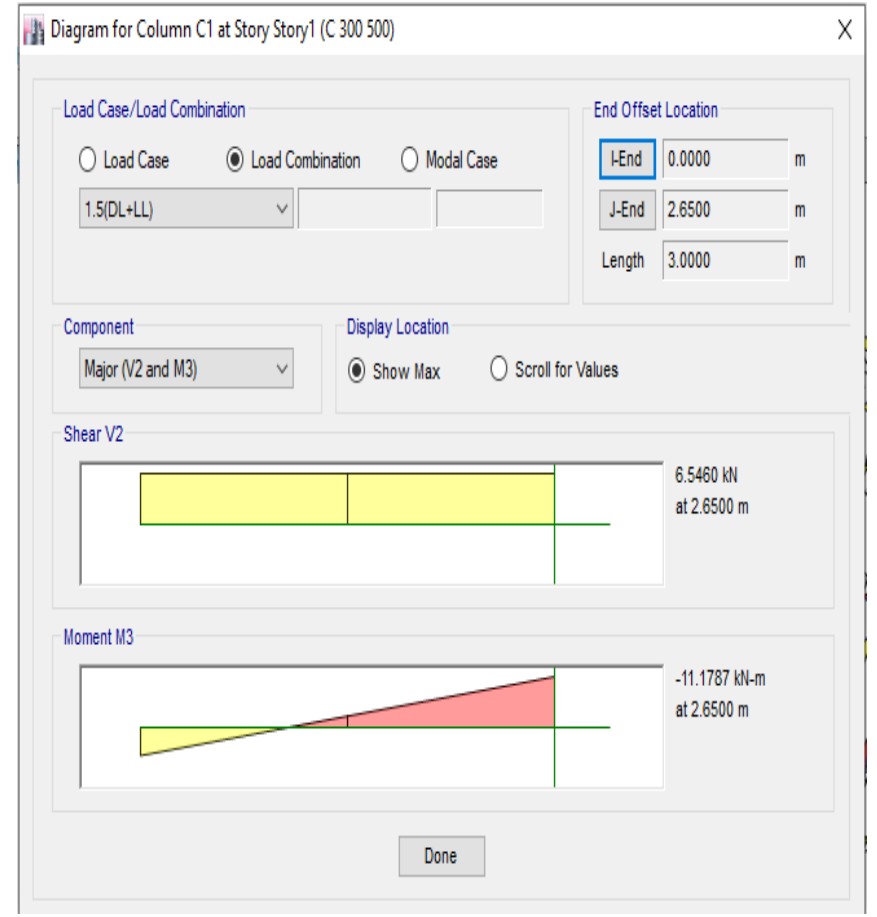

Fig.34. maximum SF and BM of Beam B14 of Light Weight building

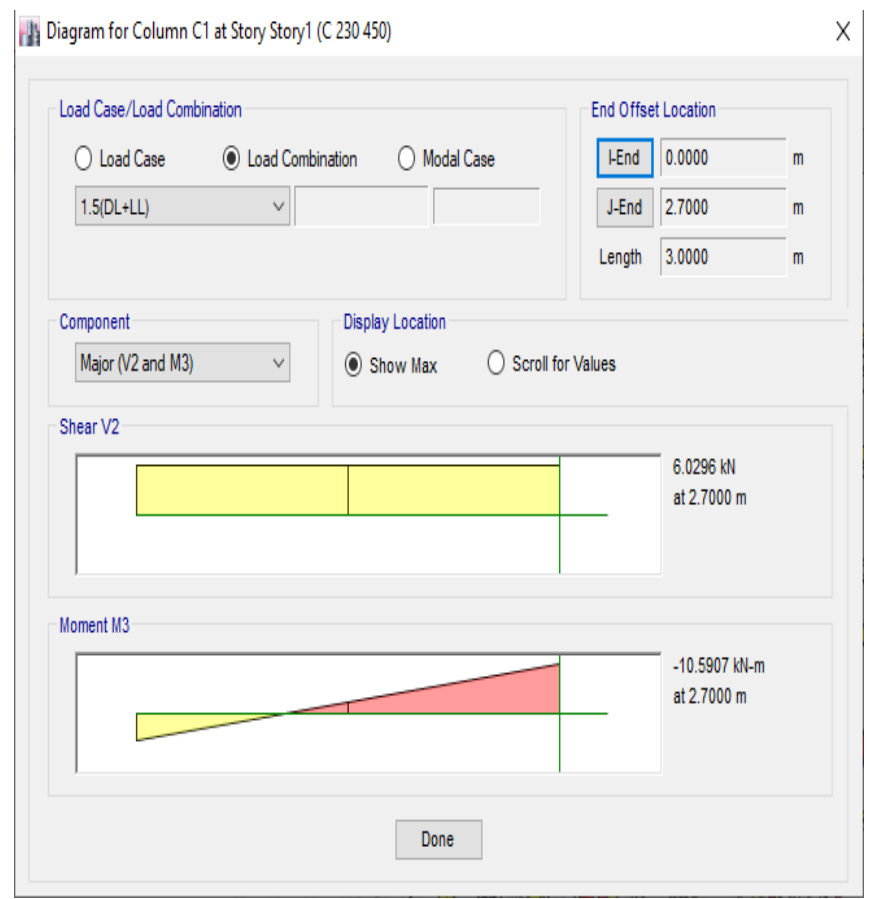

Fig.35. maximum $\mathrm{SF}$ and $\mathrm{BM}$ of column $\mathrm{C} 1$ of Light Weight building 


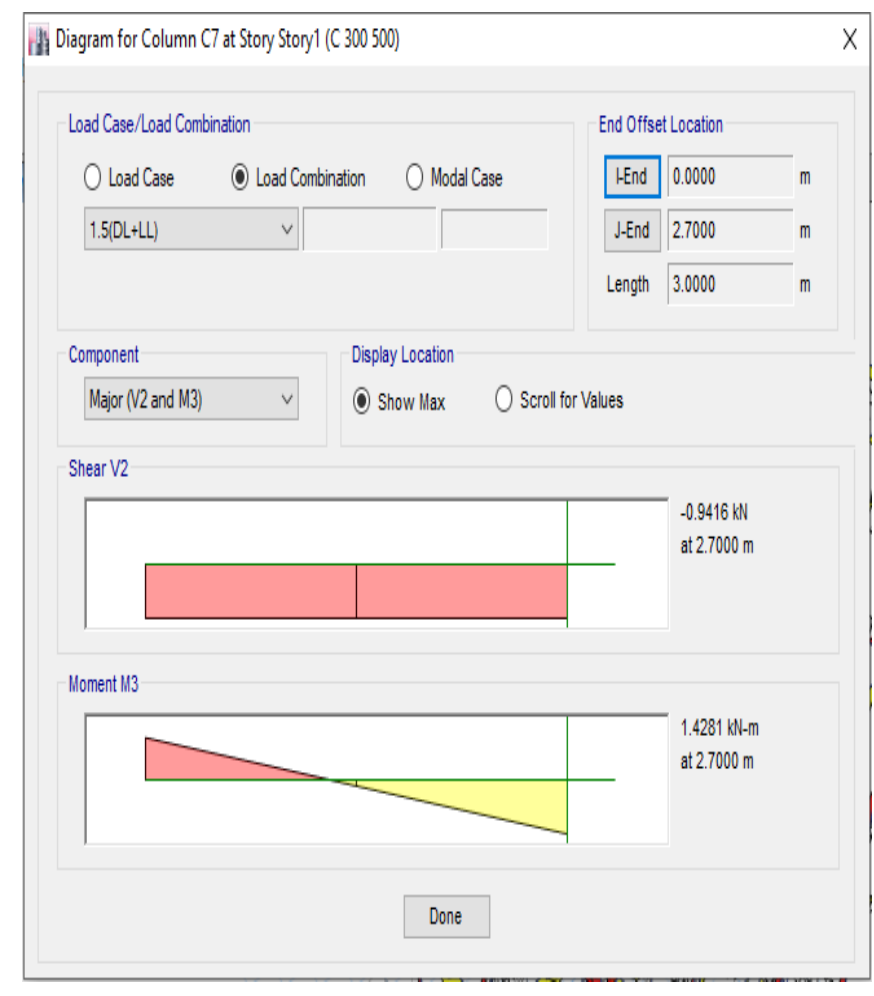

Fig.36. maximum SF and BM of Column C7 of conventional building

\section{ANALYSIS RESULTS}

Percentage of reduction in BM and SF in Corner Beam9 from figures $6.4 \& 6.5$ :

From the analysis $6.15 \%$ of shear force is reduced in light weight bricks when compared to conventional bricks. beam.

Where as $11.690 \%$ of bending moment is reduced in

Percentage of reduction in BM and SF in Corner Column1 from figures $6.8 \& 6.9$ :

$>$ From the analysis $5.260 \%$ of shear force is reduced in light weight bricks when compared to conventional bricks.

$>$ Where as $7.897 \%$ of bending moment is reduced in column.

Percentage of reduction in $\mathrm{BM}$ and $\mathrm{SF}$ in Intermediate Beam14 from figures $6.6 \& 6.7$ :

From the analysis $3.312 \%$ of shear force is reduced in light weight bricks when compared to conventional bricks

$>$ Where as $7.244 \%$ of bending moment is reduced in beam

Percentage of reduction in $\mathrm{BM}$ and $\mathrm{SF}$ in Intermediate Column7 from figures $6.10 \& 6.11$ :

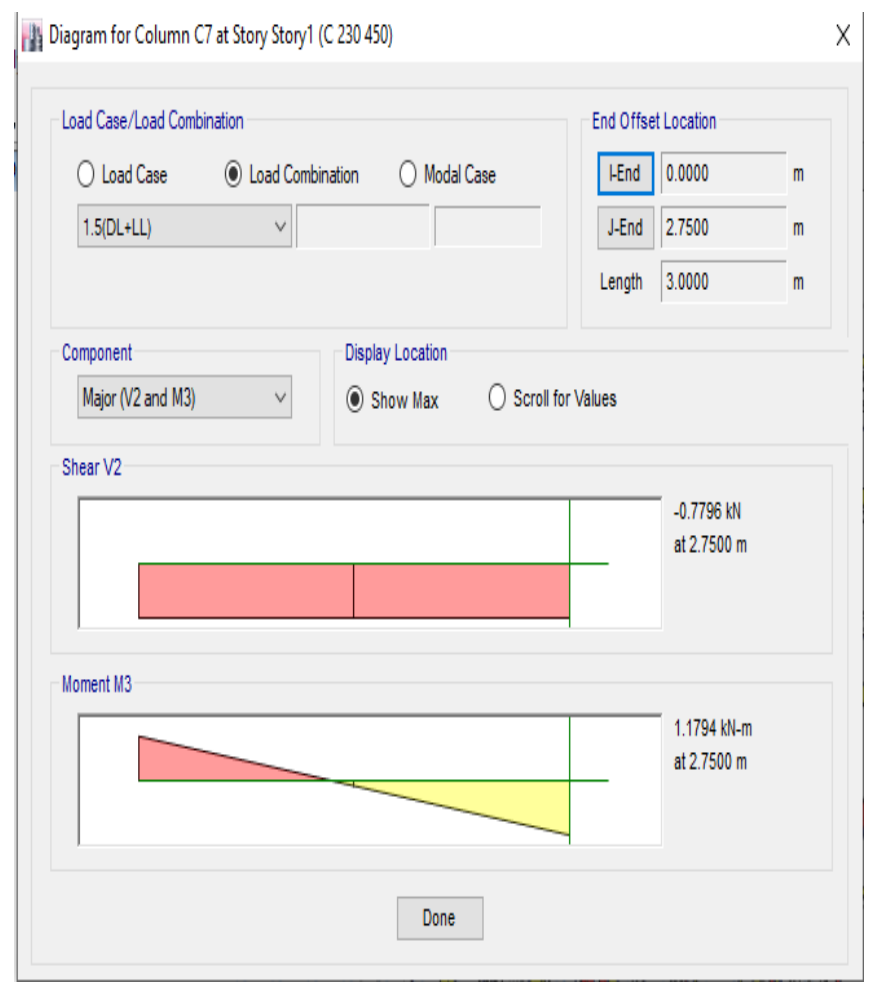

Fig.37. maximum SF and BM of Column C7 of Light Weight building

From the analysis $17.43 \%$ of shear force is reduced in light weight bricks when compared to conventional bricks.

$>$ Where as $17.21 \%$ of bending moment is reduced in column.

\section{DESIGN DATA}

\section{Concrete Frame Design}

\section{- Column details}

Table 12. Conventional Brick Column Summary

\begin{tabular}{|c|c|c|c|c|c|}
\hline Story & Label & $\begin{array}{c}\text { Station } \\
\mathbf{m m}\end{array}$ & $\begin{array}{c}\text { Load } \\
\text { combinations }\end{array}$ & $\begin{array}{c}\text { At v } \\
\mathbf{m a j o r} \\
\mathbf{m m}^{2} / \mathbf{m}\end{array}$ & $\begin{array}{c}\text { At v } \\
\mathbf{m i n o r} \\
\mathbf{m m}^{2} / \mathbf{m}\end{array}$ \\
\hline Story 1 & $\mathrm{C} 1$ & 0 & $1.5(\mathrm{DL}+\mathrm{LL})$ & 332.53 & 554.22 \\
\hline Story 1 & $\mathrm{C} 1$ & 1325 & $1.5(\mathrm{DL}+\mathrm{LL})$ & 332.53 & 554.22 \\
\hline Story 1 & $\mathrm{C} 1$ & 2650 & $1.5(\mathrm{DL}+\mathrm{LL})$ & 332.53 & 554.22 \\
\hline Story 1 & $\mathrm{C} 7$ & 0 & $1.5(\mathrm{DL}+\mathrm{LL})$ & 332.53 & 554.22 \\
\hline Story 1 & $\mathrm{C} 7$ & 1350 & $1.5(\mathrm{DL}+\mathrm{LL})$ & 332.53 & 554.22 \\
\hline Story 1 & $\mathrm{C} 7$ & 2700 & $1.5(\mathrm{DL}+\mathrm{LL})$ & 332.53 & 554.22 \\
\hline
\end{tabular}


Table 13. Light Weight Brick Column Summary

\begin{tabular}{|c|c|c|c|c|c|}
\hline Story & Label & $\begin{array}{c}\text { Station } \\
\mathbf{m m}\end{array}$ & $\begin{array}{c}\text { Load } \\
\text { combinations }\end{array}$ & $\begin{array}{c}\text { At v } \\
\mathbf{m a j o r} \\
\mathbf{m m} 2 / \mathbf{m}\end{array}$ & $\begin{array}{c}\text { At v } \\
\mathbf{m i n o r} \\
\mathbf{m m} \mathbf{2} / \mathbf{m}\end{array}$ \\
\hline $\begin{array}{c}\text { Story } \\
\mathbf{1}\end{array}$ & $\mathrm{C} 1$ & 0 & $1.5(\mathrm{DL}+\mathrm{LL})$ & 254.94 & 498.8 \\
\hline $\begin{array}{c}\text { Story } \\
\mathbf{1}\end{array}$ & $\mathrm{C} 1$ & 1350 & $1.5(\mathrm{DL}+\mathrm{LL})$ & 254.94 & 498.8 \\
\hline $\begin{array}{c}\text { Story } \\
\mathbf{1}\end{array}$ & $\mathrm{C} 1$ & 2700 & $1.5(\mathrm{DL}+\mathrm{LL})$ & 254.94 & 498.8 \\
\hline $\begin{array}{c}\text { Story } \\
\mathbf{1}\end{array}$ & $\mathrm{C} 7$ & 0 & $1.5(\mathrm{DL}+\mathrm{LL})$ & 254.94 & 498.8 \\
\hline $\begin{array}{c}\text { Story } \\
\mathbf{1}\end{array}$ & $\mathrm{C} 7$ & 1375 & $1.5(\mathrm{DL}+\mathrm{LL})$ & 254.94 & 498.8 \\
\hline $\begin{array}{c}\text { Story } \\
\mathbf{1}\end{array}$ & $\mathrm{C} 7$ & 2750 & $1.5(\mathrm{DL}+\mathrm{LL})$ & 254.94 & 498.8 \\
\hline
\end{tabular}

\section{- Corner Beam - B9}

Table 14. Conventional Brick Corner Beam Summary

\begin{tabular}{|c|c|c|c|c|c|c|}
\hline $\begin{array}{c}\text { Stor } \\
\mathbf{y}\end{array}$ & $\begin{array}{c}\text { Labe } \\
\text { I }\end{array}$ & $\begin{array}{l}\text { Statio } \\
\text { n mm }\end{array}$ & $\begin{array}{c}\text { Desig } \\
\text { n } \\
\text { sectio } \\
\text { n }\end{array}$ & $\begin{array}{c}\text { Load } \\
\text { combination } \\
\text { s }\end{array}$ & $\begin{array}{c}\text { As } \\
\text { top } \\
\text { mm } \\
2\end{array}$ & $\begin{array}{c}\text { As } \\
\text { botto } \\
\mathbf{m} \\
\mathbf{m m 2}\end{array}$ \\
\hline $\begin{array}{c}\text { Stor } \\
\text { y } 1\end{array}$ & B9 & 250 & $\begin{array}{c}230 \mathrm{x} \\
350\end{array}$ & $1.5(\mathrm{DL}+\mathrm{LL})$ & 179 & 216 \\
\hline $\begin{array}{c}\text { Stor } \\
\text { y } 1\end{array}$ & B9 & 718.3 & $\begin{array}{c}230 \mathrm{x} \\
350\end{array}$ & $1.5(\mathrm{DL}+\mathrm{LL})$ & 153 & 216 \\
\hline $\begin{array}{c}\text { Stor } \\
\text { y } 1\end{array}$ & B9 & 1186.7 & $\begin{array}{c}230 \mathrm{x} \\
350\end{array}$ & $1.5(\mathrm{DL}+\mathrm{LL})$ & 153 & 216 \\
\hline $\begin{array}{c}\text { Stor } \\
\text { y } 1\end{array}$ & B9 & 1186.7 & $\begin{array}{c}230 \mathrm{x} \\
350\end{array}$ & $1.5(\mathrm{DL}+\mathrm{LL})$ & 153 & 216 \\
\hline $\begin{array}{c}\text { Stor } \\
\text { y } 1\end{array}$ & B9 & 1582.2 & $\begin{array}{c}230 x \\
350\end{array}$ & $1.5(\mathrm{DL}+\mathrm{LL})$ & 153 & 216 \\
\hline $\begin{array}{c}\text { Stor } \\
\text { y } 1\end{array}$ & B9 & 1977.8 & $\begin{array}{c}230 \mathrm{x} \\
350\end{array}$ & $1.5(\mathrm{DL}+\mathrm{LL})$ & 153 & 216 \\
\hline $\begin{array}{c}\text { Stor } \\
\text { y } 1\end{array}$ & B9 & 2373.3 & $\begin{array}{c}230 \mathrm{x} \\
350\end{array}$ & $1.5(\mathrm{DL}+\mathrm{LL})$ & 153 & 216 \\
\hline $\begin{array}{c}\text { Stor } \\
\text { y } 1\end{array}$ & B9 & 2373.3 & $\begin{array}{c}230 \mathrm{x} \\
350\end{array}$ & $1.5(\mathrm{DL}+\mathrm{LL})$ & 153 & 216 \\
\hline $\begin{array}{c}\text { Stor } \\
\text { y } 1\end{array}$ & B9 & 2841.7 & $\begin{array}{c}230 \mathrm{x} \\
350\end{array}$ & $1.5(\mathrm{DL}+\mathrm{LL})$ & 153 & 216 \\
\hline $\begin{array}{c}\text { Stor } \\
\text { y } 1\end{array}$ & B9 & 3310.0 & $\begin{array}{c}230 \mathrm{x} \\
350\end{array}$ & $1.5(\mathrm{DL}+\mathrm{LL})$ & 184 & 216 \\
\hline & & & & & 1587 & 2160 \\
\hline
\end{tabular}

Table 15. Light Weight Brick Corner Beam Summary

\begin{tabular}{|c|c|c|c|c|c|c|}
\hline $\begin{array}{c}\text { Stor } \\
\mathbf{y}\end{array}$ & $\begin{array}{c}\text { Labe } \\
\mathbf{I}\end{array}$ & $\begin{array}{c}\text { Statio } \\
\mathbf{n ~ m m}\end{array}$ & $\begin{array}{c}\text { Desig } \\
\mathbf{n} \\
\mathbf{s e c t i o} \\
\mathbf{n}\end{array}$ & $\begin{array}{c}\text { Load } \\
\mathbf{c o m b i n a t i o n} \\
\mathbf{s}\end{array}$ & $\begin{array}{c}\text { As } \\
\mathbf{t o p} \\
\mathbf{m m} \\
\mathbf{2}\end{array}$ & $\begin{array}{c}\text { As } \\
\mathbf{b o t t o} \\
\mathbf{m} \\
\mathbf{m m 2}\end{array}$ \\
\hline $\begin{array}{c}\text { Stor } \\
\mathbf{y} \mathbf{1}\end{array}$ & $\mathrm{B} 9$ & 225 & $\begin{array}{c}230 \mathrm{x} \\
300\end{array}$ & $1.5(\mathrm{DL}+\mathrm{LL})$ & 197 & 183 \\
\hline $\begin{array}{c}\text { Stor } \\
\mathbf{y} \mathbf{1}\end{array}$ & $\mathrm{B} 9$ & 705.8 & $\begin{array}{c}230 \mathrm{x} \\
300\end{array}$ & $1.5(\mathrm{DL}+\mathrm{LL})$ & 130 & 183 \\
\hline $\begin{array}{c}\text { Stor } \\
\mathbf{y} \mathbf{1}\end{array}$ & $\mathrm{B} 9$ & 1186.7 & $\begin{array}{c}230 \mathrm{x} \\
300\end{array}$ & $1.5(\mathrm{DL}+\mathrm{LL})$ & 130 & 183 \\
\hline $\begin{array}{c}\text { Stor } \\
\mathbf{y} \mathbf{1}\end{array}$ & $\mathrm{B} 9$ & 1186.7 & $\begin{array}{c}230 \mathrm{x} \\
300\end{array}$ & $1.5(\mathrm{DL}+\mathrm{LL})$ & 130 & 183 \\
\hline $\begin{array}{c}\text { Stor } \\
\mathbf{y} \mathbf{1}\end{array}$ & $\mathrm{B} 9$ & 1582.2 & $\begin{array}{c}230 \mathrm{x} \\
300\end{array}$ & $1.5(\mathrm{DL}+\mathrm{LL})$ & 130 & 183 \\
\hline $\begin{array}{c}\text { Stor } \\
\mathbf{y} \mathbf{1}\end{array}$ & $\mathrm{B} 9$ & 1977.8 & $\begin{array}{c}230 \mathrm{x} \\
300\end{array}$ & $1.5(\mathrm{DL}+\mathrm{LL})$ & 130 & 183 \\
\hline $\begin{array}{c}\text { Stor } \\
\mathbf{y} \mathbf{1}\end{array}$ & $\mathrm{B} 9$ & 2373.3 & $\begin{array}{c}230 \mathrm{x} \\
300\end{array}$ & $1.5(\mathrm{DL}+\mathrm{LL})$ & 130 & 183 \\
\hline $\begin{array}{c}\text { Stor } \\
\mathbf{y} \mathbf{1}\end{array}$ & $\mathrm{B} 9$ & 2373.3 & $\begin{array}{c}230 \mathrm{x} \\
300\end{array}$ & $1.5(\mathrm{DL}+\mathrm{LL})$ & 130 & 183 \\
\hline $\begin{array}{c}\text { Stor } \\
\mathbf{y} \mathbf{1}\end{array}$ & $\mathrm{B} 9$ & 2854.2 & $\begin{array}{c}230 \mathrm{x} \\
300\end{array}$ & $1.5(\mathrm{DL}+\mathrm{LL})$ & 130 & 183 \\
\hline $\begin{array}{c}\text { Stor } \\
\mathbf{y} \mathbf{1}\end{array}$ & $\mathrm{B} 9$ & 3335 & $\begin{array}{c}230 \mathrm{x} \\
300\end{array}$ & $1.5(\mathrm{DL}+\mathrm{LL})$ & 201 & 183 \\
\hline & & & $\mathbf{1 4 3 8}$ & $\mathbf{1 8 3 0}$ \\
\hline
\end{tabular}

\section{- Intermediate Beam - B14}

Table 16. Conventional Brick Intermediate Beam Summary

\begin{tabular}{|c|c|c|c|c|c|c|}
\hline $\begin{array}{c}\text { Stor } \\
\mathbf{y}\end{array}$ & $\begin{array}{c}\text { Labe } \\
\quad 1\end{array}$ & $\begin{array}{l}\text { Statio } \\
\mathrm{n} \mathrm{mm}\end{array}$ & $\begin{array}{c}\text { Desig } \\
\text { n } \\
\text { sectio } \\
\text { n }\end{array}$ & $\begin{array}{c}\text { Load } \\
\text { combination } \\
\quad s\end{array}$ & $\begin{array}{c}\text { As } \\
\text { top } \\
\text { mm } \\
2\end{array}$ & $\begin{array}{c}\text { As } \\
\text { botto } \\
\text { m } \\
\text { mm2 }\end{array}$ \\
\hline $\begin{array}{c}\text { Stor } \\
\text { y } 1\end{array}$ & B14 & 250 & $\begin{array}{l}230 x \\
300\end{array}$ & $1.5(\mathrm{DL}+\mathrm{LL})$ & 164 & 183 \\
\hline $\begin{array}{c}\text { Stor } \\
\text { y } 1\end{array}$ & B14 & 718.3 & $\begin{array}{l}230 x \\
300\end{array}$ & $1.5(\mathrm{DL}+\mathrm{LL})$ & 130 & 183 \\
\hline $\begin{array}{c}\text { Stor } \\
\text { y } 1\end{array}$ & B14 & 1186.7 & $\begin{array}{l}230 x \\
300\end{array}$ & $1.5(\mathrm{DL}+\mathrm{LL})$ & 130 & 183 \\
\hline $\begin{array}{c}\text { Stor } \\
\text { y } 1\end{array}$ & B14 & 1186.7 & $\begin{array}{l}230 x \\
300\end{array}$ & $1.5(\mathrm{DL}+\mathrm{LL})$ & 130 & 183 \\
\hline $\begin{array}{c}\text { Stor } \\
\text { y } 1\end{array}$ & B14 & 1582.2 & $\begin{array}{l}230 x \\
300\end{array}$ & $1.5(\mathrm{DL}+\mathrm{LL})$ & 130 & 183 \\
\hline $\begin{array}{c}\text { Stor } \\
\text { y } 1\end{array}$ & B14 & 1977.8 & $\begin{array}{l}230 \mathrm{x} \\
300\end{array}$ & $1.5(\mathrm{DL}+\mathrm{LL})$ & 130 & 183 \\
\hline $\begin{array}{c}\text { Stor } \\
\text { y } 1\end{array}$ & B14 & 2373.3 & $\begin{array}{l}230 x \\
300\end{array}$ & $1.5(\mathrm{DL}+\mathrm{LL})$ & 130 & 183 \\
\hline $\begin{array}{c}\text { Stor } \\
\text { y } 1\end{array}$ & B14 & 2373.3 & $\begin{array}{l}230 x \\
300\end{array}$ & $1.5(\mathrm{DL}+\mathrm{LL})$ & 130 & 183 \\
\hline $\begin{array}{c}\text { Stor } \\
\text { y } 1\end{array}$ & B14 & 2841.7 & $\begin{array}{l}230 x \\
300\end{array}$ & $1.5(\mathrm{DL}+\mathrm{LL})$ & 130 & 183 \\
\hline $\begin{array}{c}\text { Stor } \\
\text { y } 1\end{array}$ & B14 & 3310.0 & $\begin{array}{l}230 x \\
300\end{array}$ & $1.5(\mathrm{DL}+\mathrm{LL})$ & 170 & 183 \\
\hline & & & & & 1374 & 1830 \\
\hline
\end{tabular}

Table 17. Light Weight Brick Intermediate Beam Summary 


\begin{tabular}{|c|c|c|c|c|c|c|}
\hline $\begin{array}{c}\text { Stor } \\
\mathbf{y}\end{array}$ & $\begin{array}{c}\text { Labe } \\
\mathbf{l}\end{array}$ & $\begin{array}{c}\text { Statio } \\
\mathbf{n ~ m m}\end{array}$ & $\begin{array}{c}\text { Desig } \\
\mathbf{n} \\
\mathbf{s e c t i o} \\
\mathbf{n}\end{array}$ & $\begin{array}{c}\text { Load } \\
\mathbf{c o m b i n a t i o n} \\
\mathbf{s}\end{array}$ & $\begin{array}{c}\text { As } \\
\mathbf{t o p} \\
\mathbf{m m} \\
\mathbf{2}\end{array}$ & $\begin{array}{c}\text { As } \\
\text { botto } \\
\mathbf{m} \\
\mathbf{m m} 2\end{array}$ \\
\hline $\begin{array}{c}\text { Stor } \\
\mathbf{y} \mathbf{1}\end{array}$ & $\mathrm{B} 14$ & 225 & $\begin{array}{c}230 \mathrm{x} \\
250\end{array}$ & $1.5(\mathrm{DL}+\mathrm{LL})$ & 196 & 150 \\
\hline $\begin{array}{c}\text { Story } \\
\mathbf{1}\end{array}$ & $\mathrm{B} 14$ & 705.8 & $\begin{array}{c}230 \mathrm{x} \\
250\end{array}$ & $1.5(\mathrm{DL}+\mathrm{LL})$ & 106 & 150 \\
\hline $\begin{array}{c}\text { Stor } \\
\mathbf{y} \mathbf{1}\end{array}$ & $\mathrm{B} 14$ & 1186.7 & $\begin{array}{c}230 \mathrm{x} \\
250\end{array}$ & $1.5(\mathrm{DL}+\mathrm{LL})$ & 106 & 150 \\
\hline $\begin{array}{c}\text { Stor } \\
\mathbf{y} \mathbf{1}\end{array}$ & $\mathrm{B} 14$ & 1186.7 & $\begin{array}{c}230 \mathrm{x} \\
250\end{array}$ & $1.5(\mathrm{DL}+\mathrm{LL})$ & 106 & 150 \\
\hline $\begin{array}{c}\text { Stor } \\
\mathbf{y} \mathbf{1}\end{array}$ & $\mathrm{B} 14$ & 1582.2 & $\begin{array}{c}230 \mathrm{x} \\
250\end{array}$ & $1.5(\mathrm{DL}+\mathrm{LL})$ & 106 & 152 \\
\hline $\begin{array}{c}\text { Stor } \\
\mathbf{y} \mathbf{1}\end{array}$ & $\mathrm{B} 14$ & 1977.8 & $\begin{array}{c}230 \mathrm{x} \\
250\end{array}$ & $1.5(\mathrm{DL}+\mathrm{LL})$ & 106 & 150 \\
\hline $\begin{array}{c}\text { Stor } \\
\mathbf{y} \mathbf{1}\end{array}$ & $\mathrm{B} 14$ & 2373.3 & $\begin{array}{c}230 \mathrm{x} \\
250\end{array}$ & $1.5(\mathrm{DL}+\mathrm{LL})$ & 106 & 150 \\
\hline $\begin{array}{c}\text { Stor } \\
\mathbf{y} \mathbf{1}\end{array}$ & $\mathrm{B} 14$ & 2373.3 & $\begin{array}{c}230 \mathrm{x} \\
250\end{array}$ & $1.5(\mathrm{DL}+\mathrm{LL})$ & 106 & 150 \\
\hline $\begin{array}{c}\text { Stor } \\
\mathbf{y} \mathbf{1}\end{array}$ & $\mathrm{B} 14$ & 2854.2 & $\begin{array}{c}230 \mathrm{x} \\
250\end{array}$ & $1.5(\mathrm{DL}+\mathrm{LL})$ & 106 & 150 \\
\hline $\begin{array}{c}\text { Stor } \\
\mathbf{y} \mathbf{1}\end{array}$ & $\mathrm{B} 14$ & 3335 & $\begin{array}{c}230 \mathrm{x} \\
250\end{array}$ & $1.5(\mathrm{DL}+\mathrm{LL})$ & 203 & 150 \\
\hline & & & $\mathbf{1 2 4 7}$ & $\mathbf{1 5 0 2}$ \\
\hline
\end{tabular}

\section{DATA RESULTS}

Corner Beam Details of Conventional Brick and Light Weight Bricks:

From the above tables, we observed that the area of top reinforcement in light weight brick decreases upto $9.4 \%$ and also $15.28 \%$ area of bottom reinforcement decreased in light weight brick compared to conventional brick.

Intermediate Beam Details of Conventional Brick and Light Weight Bricks:

From the above tables, we observed that the area of top reinforcement in light weight brick decreases upto $9.2 \%$ and also $17.92 \%$ area of bottom reinforcement decreased in light weight brick compared to conventional brick.

\section{CONCLUSIONS}

The following conclusions can be enumerated point wise as follows:

1. In Beams, considering light weight bricks effect, the values of bending moment, shear force, area of reinforcement is less compared to conventional bricks.

2. The bending moment in light weight bricks decreased upto $11 \%$ and also shear force in light weight bricks decreased upto $8.03 \%$.so there is a reduction in the size of the sections.
3. The area of reinforcement in light weight bricks of columns decreased upto $16.66 \%$

4. The area of reinforcement in light weight bricks of corner beams decreased upto $12.34 \%$ and area of reinforcement in light weight bricks of intermediate beams decreased upto $13.56 \%$.

\section{References:}

1. 'Diagnosis and Assessment of Concrete Structures'State of the Art Report; CEB Bulletin d'information N. 192; International Federation for Structural Concrete (FIB): Lausanne, Switzerland, January 1989.

2. R Polder, C Andrade, B Elsener, J Gulikers, R Weidert, M Raupach, 'Recommendations of RILEM TC 154-EMC: Electrochemical techniques for measuring metallic corrosion. Test method for on-site measurement of resistivity of concrete. Mater. Struct. 2003, 36, 461-471

3. Srinivasa Rao D, Sandhya Rani MN, Sarfaraz Nawaz Syed and Suresh Kumar Tummala, E3S Web of Conferences 8701003 (2019)

4. Sateesh, N., Sampath Rao, P., Ravishanker, D.V., Satyanarayana, K (2015). 'Effect of Moisture on GFRP Composite Materials (2015) Materials Today: Proceedings, 2 (4-5), pp. 2902-2908

5. Devi, G.N., Saranya, J., Manjubaashini, N., Thangadurai, T.D., Roopan, S.M., Chitra, S (2017), 'Polyamidoaminoepichlorohydrin resin a novel synthetic anti-corrosive water soluble polymer for mild steel' , Progress in Organic Coatings, 109, pp. 117-125.

6. Bankupalli, P.T., Srikanth Babu, V., Suresh Kumar. $\mathrm{T}$, International Journal of Applied Engineering Research, 10(16), pp. 37057-37062, 2015

7. T.Srinivas and M.Abinay Raj (2019), "Seismic Effect on Design of Residential Multi-Storey Building (Stilt+17 Floors) in Zone-III and Zone-IV using Etabs", International Journal of Engineering and Advanced Technology (IJEAT), ISSN: 2249 - 8958, Volume-8, Issue-6, August 2019, pp 4662-4666. 